\title{
Structural and metamorphic evolution of the Camughera - Moncucco, Antrona and Monte Rosa units southwest of the Simplon line, Western Alps
}

\author{
Lukas M. Keller, Maurus Hess, Bernhard Fügenschuh \& Stefan M. Schmid
}

Key words: Western Alps, Camughera-Moncucco, structural analysis, kinematics, metamorphism, exhumation, transpression

\begin{abstract}
This structural and petrological study examines relationships between Alpine deformation and metamorphism in the Camughera-Moncucco, Antrona and northeastern Monte Rosa units, and it correlates major late stage deformation structures, such as the Vanzone antiform and Simplon normal fault. D1/D2 deformation and related top-N or top-NW thrusting started under high-pressure conditions (12.5-16 kbar) at relatively high temperatures (c. $\left.620-700^{\circ} \mathrm{C}\right)$. Petrological and structural data, together with published radiometric data, suggest that top-SE shearing within the structural top of the high-pressure units in the upper Penninic Alps is coeval with top-N or top-NW thrusting at their structural base. This suggests differential ascent of high-pressure units relative to the surrounding units during nappe stacking and associated crustal shortening. Barrovian metamorphism in the upper Penninic Alps is related to a first phase of backfolding, active between c. 35 Ma and c. 29-26 Ma ago (D3). D3 involves dextral shearing, combined with top-WSW shearing and orogen-parallel extension. Unroofing by orogen-parallel extension delays cooling during decompression and leads to isothermal decompression after the high-pressure stage. Towards deeper structural levels in the east, D3 deformation becomes progressively younger and prevailed at increasingly higher temperatures. Hence, compared to the higher structural levels further west, the brittle-ductile transition occurs later in the Ossola valley. Masera synform and Brevettola antiform form an open fold pair and represent the eastern continuation of the major Vanzone antiform (D4). Normal faulting across the Simplon line overlaps in time with the formation of these major D4 backfolds. Displacement along the Simplon normal fault decreases to insignificant values towards the southeast. Contemporaneous dextral shearing, however, occurs within the southern limbs of the Vanzone and Brevettola antiforms.
\end{abstract}

\section{ZUSAMMENFASSUNG}

Diese strukturelle und petrologische Arbeit untersucht die Beziehungen zwischen alpiner Deformation und Metamorphose in den Camughera-Moncucco und Antrona Einheiten sowie in der nordöstlichen Monte Rosa Decke. Zusätzlich werden grossräumige spätalpine Strukturelemente, wie die Vanzone Antiform und die Simplon Abschiebung, in einen Zusammenhang gebracht. Die D1/D2 Deformationsphase ist mit nach N oder NW gerichteten Überschiebungen assoziiert, welche anfänglich unter Hochdruckbedingungen (12.5-16 kbar) und relativ hohen Temperaturen $\left(\right.$ c. $\left.620-700^{\circ} \mathrm{C}\right)$ aktiv waren. Petrologische und strukturelle Daten, sowie publizierte radiometrische Daten, vermuten, dass SE gerichtete Abschiebungen im oberen Teil der penninischen Hochdruckeinheiten gleichzeitig mit nach NW gerichteten Überschiebungen an deren Basis aktiv waren. Dies legt es nahe, dass die Hochdruckeinheiten während der Deckenbildung und Krustenverkürzung relativ zu den umgebenden Einheiten differentiell aufgestiegen sind. Die Metamorphose vom Barrow-Typ in den oberen penninischen Einheiten steht in engem Zusammenhang mit der ersten Rückfaltungsphase, welche nach ca. 35 Mio Jahren und vor ca. 29-26 Mio Jahren aktiv war (D3). D3 beinhaltet dextrale Scherung, kombiniert mit nach WSW gerichteter Scherung und Dehnung parallel zum Orogen. Abnehmende Überlagerungsmächtigkeit durch orogen-parallele Dehnung verzögert die Abkühlung während der Dekompression und führt zu isothermaler Dekompression, nach dem Hochdruckstadium. $\mathrm{Zu}$ den tieferen strukturellen Ebenen im Osten hin wird die D3 Deformation fortschreitend jünger und ist höher temperiert. Der spröd-duktil Übergang im Ossola Tal fand deshalb zu einem späteren Zeitpunk statt als in den höheren strukturellen Ebenen im Westen. Masera Synform und Brevettola Antiform bilden ein offenes syn-D4 Faltenpaar, welches die östliche Fortsetzung der Vanzone Antiform repräsentiert. Der Versatz an der Simplon Abschiebung stirbt nach Südosten hin graduell aus. Gleichzeitige (syn-D4) dextrale Scherung ist aber in den südlichen Schenkeln von Vanzone Antiform und Brevettola Antiform zu finden.

\section{Introduction}

For a long time high-pressure metamorphism in the upper Penninic units of Western Switzerland was supposed to be of Cretaceous age (e.g. review by Hunziker et al. 1992). Consequently, parts of the tectonic structures observed west of the Lepontine dome were correlated with a Cretaceous high-pres-

sure metamorphic event. Also, fast exhumation was widely believed to have occurred before the Tertiary (Steck \& Hunziker 1994).

Recently, an increasing amount of isotopic studies, combined with structural arguments, pointed towards a Tertiary

Department of Earth Sciences, Basel University, Bernoullistrasse 32, CH-4056 Basel, Switzerland. E-mail: Lukas.Keller@unibas.ch 




Fig. 1. Tectonic overview and localities in the working area

a) Tectonic map of the western part of the Penninic Alps modified after "Tektonische Karte der Schweiz" (Spicher, 1976) and outline of the study area. The mapped mineral zone boundaries characteristic for Barrovian metamorphism are: 1: sillimanite and staurolite mineral zone boundaries after Niggli (1970), 2: staurolite mineral zone boundary after Reinhardt (1966), 3: staurolite and sillimanite mineral zone boundaries after Keller et al. (2005a), albite-oligoclase: isograde after Bearth (1958). The abbreviations of tectonic units are: $\mathrm{MR}=$ Monte Rosa nappe, $\mathrm{CM}=\mathrm{Ca}$ mughera-Moncucco unit, ZS=Zermatt-Saas ophiolites, $\mathrm{AN}=$ Antrona ophiolites, $\mathrm{PG}=$ Portjengrat unit, $\mathrm{ML}=$ Monte Leone nappe, $\mathrm{AM}=$ Aar Massive, $\mathrm{GM}=$ Gotthard Massive, $\mathrm{A}=$ Antigorio nappe, $\mathrm{PCZ}=$ Pioda di Crana zone, MA=Maggia nappe, BN=Grand StBernhard nappe system, SL=Sesia zone, $\mathrm{BR}=$ Berisal nappe

b) River system (black lines) and towns/villages (grey shaded areas and circles, partly connected by roads). White areas: lakes, black triangles: mountain peaks, parallel lines: passes.

age for high-pressure metamorphism in the Penninic units of the Western Alps (Froitzheim et al. 1996; Gebauer 1999). In the Western Alps west of the Lepontine dome re-equilibration occurred under greenschist facies conditions and in the context of backthrusting, dated as late Eocene to Early Oligocene (Hunziker \& Bearth 1969; Hunziker 1969; Barnicoat et al. 1995; Markley et al. 1998). This suggests that Tertiary-age high-pressure metamorphism was immediately followed by fast exhumation.

The studied area is situated southeast of the Simplon line (Fig. 1) and at the eastern margin of the Lepontine dome
(Merle et al. 1989), where the metamorphic zonation indicates a metamorphic grade that increases downward and eastwards. While the relatively higher structural units in the west reached greenschist facies conditions during decompression (Bearth 1958; Colombi 1989; Frey et al. 1974, 1999), the relatively lower units in the east reached Barrovian P-T conditions upon decompression from the high-pressure stage (Engi et al. 2001a; Keller et al. 2005a). Such along-strike changes in metamorphic grade upon decompression suggest that the P-T history related to a particular deformation phase may also change from west to east and into the Lepontine dome. 
From a regional point of view, there is a wealth of studies on the structure and tectonics of the Camughera-Moncucco (CM) unit and adjacent units (Blumenthal 1952; Bearth 1957a; Reinhard 1966; Laduron 1976; Klein 1978; Steck 1984, 1987) in the working area (Fig.1). At least 4 phases of deformation are observed (Gosso et al. 1979; Milnes et al. 1981). Early shearing and mylonitisation started under eclogite facies conditions in the Monte Rosa unit and adjacent Furgg Zone (Keller \& Schmid 2001; Dal Piaz 2001). This nappe stacking continued during D2, related to exhumation, since D2 deformation under greenschist facies conditions is still associated with the same kinematic regime (Keller \& Schmid 2001). So far high-pressure metamorphism was not yet documented in the underlying $\mathrm{CM}$ unit. A major switch in the kinematic regime occurred after D2, resulting in the formation of a first set of backfolds (D3) and contemporaneous dextral shearing. A second backfolding phase D4 formed the major Vanzone antiformal backfold (Bearth 1957a; Laduron 1976). However the location of its axial trace becomes ambiguous towards the east. According to Milnes et al. (1981) the Vanzone backfold is supposed to become increasingly tighter towards the east, associated with a complete transposition of older foliations. On the other hand, Klein (1978) proposed open folding during D4 (his "Brevettola antiform") further to the east.

The relative timing and kinematics during the formation of the major Vanzone antiform and normal faulting in the Simplon fault zone, respectively, represent a second yet unresolved issue. Klein (1978) proposed that the Miocene-age Simplon normal fault (Grasemann \& Mancktelow 1993) postdated the Vanzone antiform (and its eastern equivalent, the Brevettola antiform), supposedly cutting its axial plane. Steck \& Hunziker (1994) argue along a similar direction and regard the formation of both generations of backfolds (i.e. the D3 Mischabel and the D4 Vanzone folds) as Oligocene in age, and hence predating the Simplon normal fault. Furthermore, these authors associate the formation of both sets of backfolds with dextral shearing that started as early as $35 \mathrm{Ma}$ ago. A different view is taken by Milnes et al. (1981) and Mancktelow (1992), who propose that the formation of the Vanzone antiform is contemporaneous with the formation of the Simplon normal fault, and hence Miocene in age (Grasemann \& Mancktelow 1993).

In summary, this study focuses on the gneissic units situated southwest of the Simplon line, and aims at revealing relationships between deformation and metamorphism. Thereby examining as to how far Tertiary age high-pressure overprint and associated deformation also affected the units southwest of the Simplon line. Furthermore cause and nature of the late Alpine Vanzone antiform are investigated. In the context of late stage backfolding and possibly associated normal and/or strike slip faulting, the mapping of the axial trace of the Vanzone antiform in the vicinity of the Simplon normal fault and the Centovalli fault zone turned out to be crucial regarding the significance and the timing of these late Alpine structures. New fission track data obtained from the area of the Ossola valley (Hess 2003) provide additional constraints regarding the latest stages of the exhumation history.

\section{Geological setting}

The Antrona ophiolitic unit separates the Monte Rosa nappe and CM unit from each other. According to Schmid et al. (2004) the three units are part of the Penninic and Sub-Penninic nappes located southwest of the Lepontine dome and of the Simplon line (Fig. 1). Due to S-vergent backfolding and associated axial plunge towards SW the former nappe pile can be seen as a distorted profile in map view (e.g. Klein 1978; Milnes et al. 1981; Escher et al. 1997). The Sub-Penninic CM unit forms the core of the Vanzone antiform (e.g. Bearth 1957, Fig. 1). Further west the middle Penninic Monte Rosa nappe is overlain by the upper Penninic Zermatt-Saas ophiolites (Fig. 1).

Zermatt-Saas ophiolites, Monte Rosa nappe, Antrona ophiolites and CM unit have experienced regional high-pressure metamorphism (Frey et al. 1974, 1999; Keller et al. 2005a). During decompression upon the high-pressure stage the eastern and structurally lower parts of the Monte Rosa nappe, the Antrona ophiolites and the CM unit experienced amphibolite facies metamorphism, whereas the western and structurally higher part of the Monte Rosa nappe only underwent greenschist facies overprint (Frey et al. 1974, 1999; Keller et al. 2005a). Bearth (1958) was the first to recognise this metamorphic zonation by mapping the albite-oligoclase boundary in the study area (Fig. 1). This zonation indicates a metamorphic field gradient, whereby temperatures increase eastwards and downwards. Temperatures estimated for the Antrona ophiolites of the study area range between $600-700^{\circ} \mathrm{C}$ (Colombi 1989, his Fig. 6-2E). Concerning the high-pressure stage in the Antrona ophiolites, a minimum pressure around 14-16 kbars at $480-720^{\circ} \mathrm{C}$ is obtained (Colombi \& Pfeifer 1986). Within the $\mathrm{CM}$ unit several occurrences of staurolite and kyanite are known (Merlyn 1977 his Fig. 14). However, according to Keller et al. (2005a) the CM unit west of the Ossola valley reached P-T conditions of about $12.5-16 \mathrm{kbar}$ at $620-700^{\circ} \mathrm{C}$ during a highpressure stage. There, sillimanite grade at P-T conditions of about $650^{\circ} \mathrm{C}$ at $5 \mathrm{kbar}$, was reached during almost isothermal decompression and after the high-pressure stage (Fig. 1).

\section{Mapping of the Boundaries between tectonic units}

The tectonic boundaries drawn in this study (Fig. 2) follow in great part those outlined in the new tectonic map of the Western Swiss Alps (Steck et al. 1999, 2001), based on the principle that Permo-Mesozoic cover rocks or ophiolitic remnants of former oceanic crust define major nappe contacts. Deviations of Figure 2 from the interpretation given in the new tectonic map of Steck et al. (1999) are discussed below.

(i) The Furgg zone (Bearth 1953, 1954a, 1954b, 1956a, 1957b; Wetzel 1972) is attributed to the continental Portjengrat unit as suggested by Keller \& Schmid (2001), rather than 


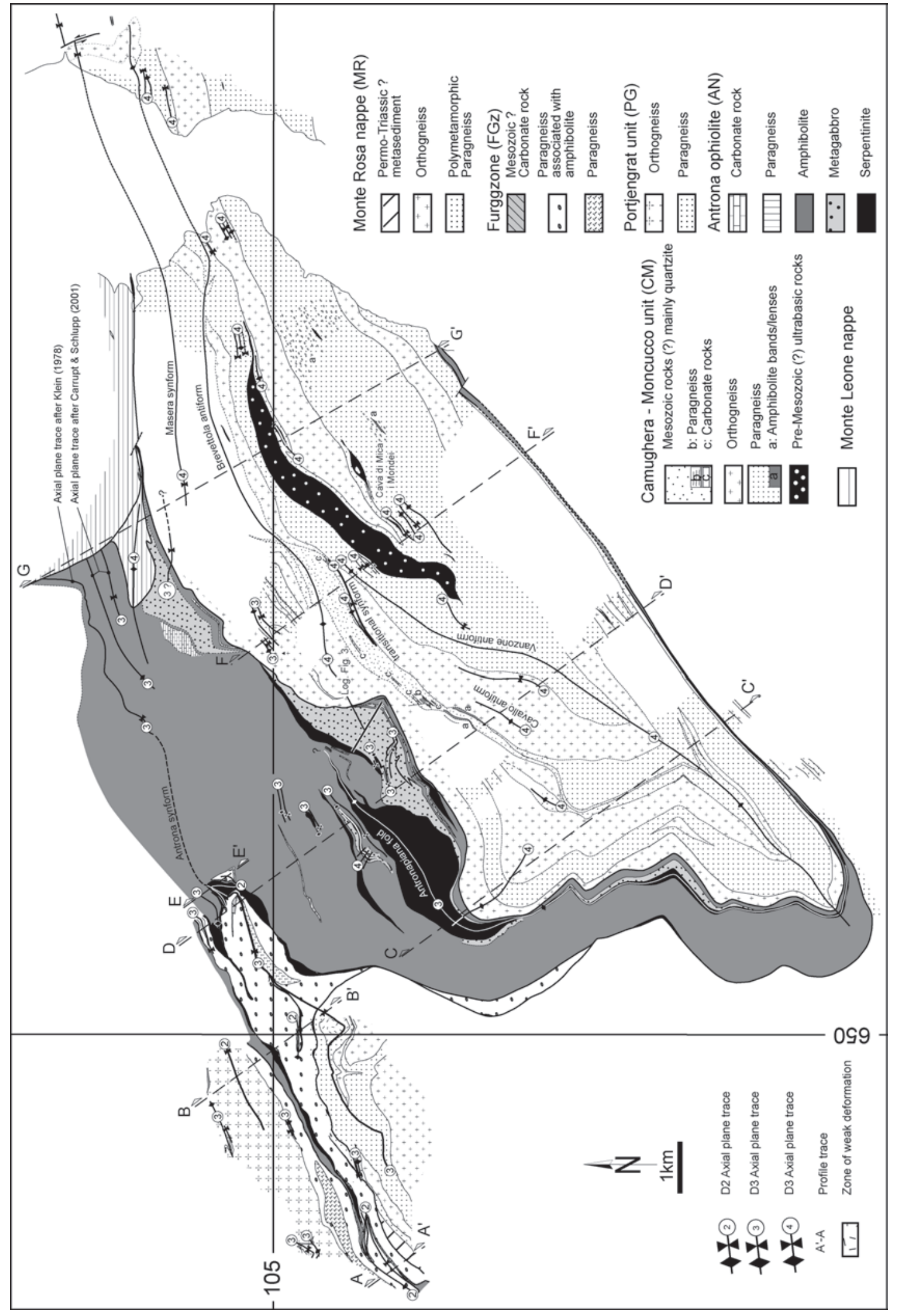

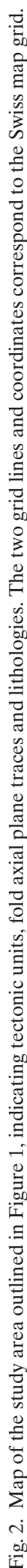


to the Monte Rosa nappe. Based on this interpretation the area around the north-eastern termination of the Monte Rosa nappe is subdivided into Monte Rosa nappe, Portjengrat-Furgg unit and Antrona ophiolites (Fig. 2).

(ii) This study verified the observations by Bearth (1939) that the Antrona ophiolites (metagabbros, amphibolites and serpentinites) continue along strike much further to the east than shown in the tectonic map of Steck et al. (1999) in the Bognanco valley. There, interrelationships between tectonic boundaries have long been debated (e.g. Bearth 1939, 1956b; Blumenthal 1952; Amstutz 1954). At the locality "Bosco" (Fig. 1b), situated on the southern slope of the Bognanco valley, rocks derived from the Antrona ophiolites still have a thickness of more than one hundred meters (Fig. 2). Further to the east, and along strike of Bosco, ophiolites are again found slightly west and east of the locality S. Marco (Fig. 1b; see also Bearth 1956b). The easternmost continuation of this ophiolitic suite (serpentinites) is found on the floor of the river Bogna at the mouth of the Bognanco valley, near Cisore (Fig. 1b, see also Novarese \& Stella 1913; Bearth 1956b). Hence, rocks derived from the Antrona ophiolities can be traced all along the lower Bognanco valley and define the contact between CM unit and Monte Leone nappe (Fig. 2).

(iii) Steck et al. (1999) attribute crystalline rocks situated around Terme di Bognanco to the CM unit. However, these rocks are separated by Antrona ophiolites from the CM unit and are therefore laterally connected with and attributed to the Monte Leone nappe, as previously mapped by Bearth (1939, his Fig. 6).

\section{Lithostratigraphy of the Camughera-Moncucco unit and Antrona ophiolites}

Concerning the lithostratigraphy of the eastern part of the Monte Rosa Nappe and the Portjengrat-Furgg unit, the reader is referred to Bearth (1954a, 1954b), Jaboyedoff et al. (1996) and Keller \& Schmid (2001). This study primarily addresses the lithology of the CM unit and the Antrona ophiolitic unit. The lithostratigraphy of all these units, including that of the Monte Leone nappe described by Bearth (1939, 1956b), is an important base of the tectonic map and the cross-sections given in Figures 2 and 7.

\section{Camughera-Moncucco unit}

The CM basement unit may be subdivided into the Moncucco zone and the overlying Camughera zone, the two being partly separated by a series of aligned lenses of marbles and quarzites of supposed Mesozoic age, the so-called "Salarioli-Mulde" (Bearth 1939, 1956b). Both units predominantly comprise different types of paragneisses and orthogneisses of supposed pre-Mesozoic age. Since the same rock types are found in both zones, a difference can only be made on the basis of the relative abundance of paragneisses and orthogneisses, respectively
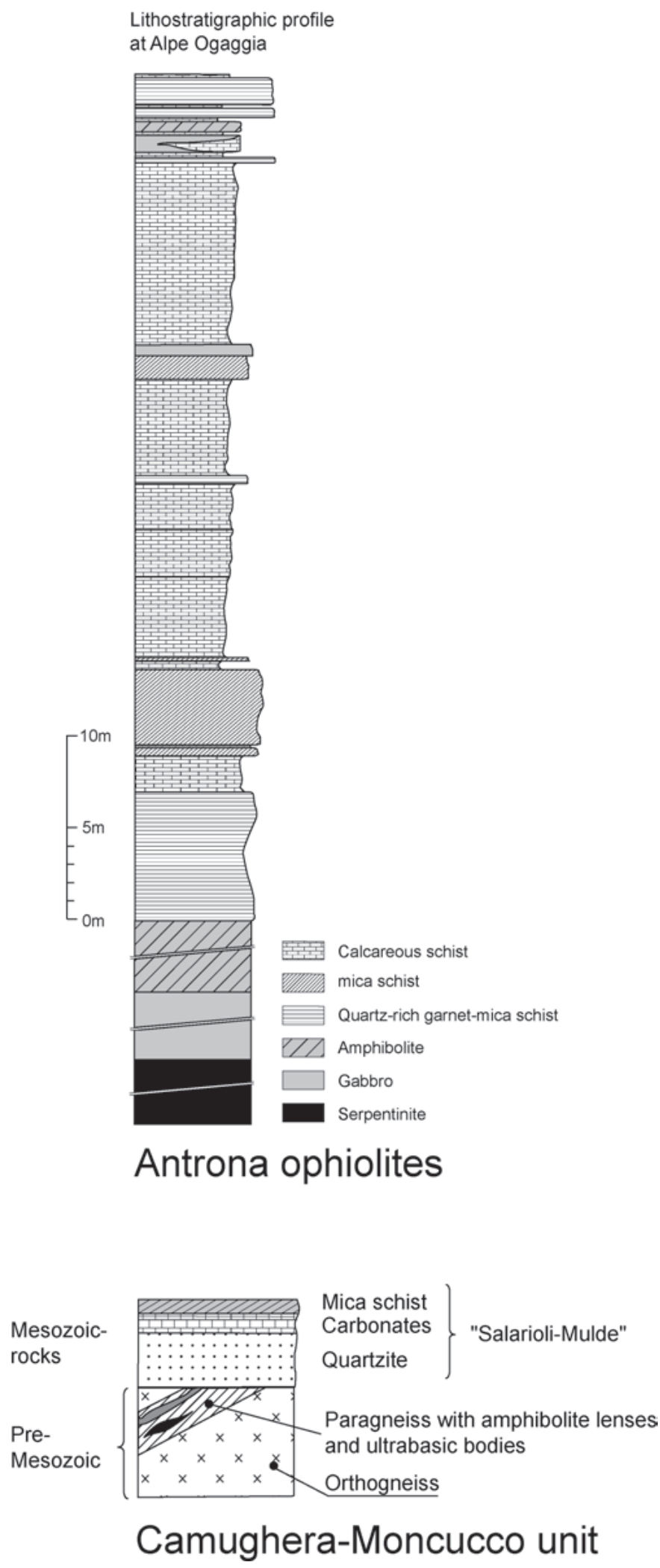

Fig. 3. Lithostratigraphic profile of the Antrona ophiolites taken at Alpe Ogaggia (see Fig. 2 for location and synthetic lithostratigraphic profile of the Camughera-Moncucco unit. 
(Figs. 2, 3, Bearth 1956b): orthogneisses (partly coarse-grained augengneisses) are preferentially found in the Camughera zone, paragneisses dominate in the Moncucco zone (Fig. 2). A $\mathrm{Rb}-\mathrm{Sr}$ age obtained for orthogneisses from the Moncucco zone gives $271 \pm 4.8 \mathrm{Ma}$, indicating a late Hercinyan age for the intrusion of the metagranites (Bigioggero et al. 1981). Mafic lenses are found in paragneisses of both units, but more frequently in the Moncucco zone (Figs. 2, 3). The paragneisses of the Moncucco zone also contain peridotites, which are partly transformed into talc schists (Bearth 1956b) and serpentinites. These ultramafic rocks form a larger body, as well as several smaller lenses and boudins mostly located south of this larger body (Fig. 2; e.g. Bearth 1956b; Laduron 1976; Merlyn 1977). One of these ultramafic boudins, located at I Mondei ("Cava di Mica"; Fig. 2), is clearly intruded by a pegmatite. Rb-Sr dating of coarse-grained muscovite originating from this pegmatite gives ages of about 200 Ma (Ferrara et al. 1962). This strongly supports the suggestion by Bearth (1956b), who attributed a pre-Mesozoic age to the peridotites of the Moncucco zone.

The supposed Mesozoic cover in the "Salarioli-Mulde" mainly consists of marbles and quartz-mica schists, the latter being mostly in direct contact with the pre-Mesozoic basement (Fig. 3). Bearth (1939, his Fig. 7) also reports serpentinites to be associated with the rocks of the "Salarioli-Mulde", supposedly found between Alpe Cavallo and Passo di Ogaggia (Antrona Valley; Fig. 1b). However, we could not confirm the existence of such serpentinites. Instead we found greenish coloured metapelites, mainly formed by chlorite, but also containing garnet and staurolite, completely surrounded by the other lithologies of the "Salarioli-Mulde". Hence, according to our findings, the "Salarioli-Mulde" lacks ophiolitic rocks. Note, that the CM unit is almost completely surrounded by the Mesozoic rocks of the Antrona ophiolites in the study area, while the "Salarioli-Mulde" is nowhere visibly interconnected with the Antrona ophiolitic unit (see also Blumenthal 1952). Furthermore, the "Salarioli-Mulde" wedges out at Passo Salarioli south of the Antrona valley (Fig. 2), and a tectonic contact between Camughera zone and Moncucco zone can no more be observed farther to the east (see also Bearth 1939). This, together with the lithological similarities described above, indicates that the "Salarioli-Mulde" formed by infolding or wedging of metasediments into a single CamugheraMoncucco tectonic unit or nappe. In this study Mesozoic ophiolites are restricted to the overlying Antrona ophiolite complex.

So far several solutions have been proposed for mutually connecting the different subunits forming the nappe pile of the Simplon-Pennine Alps. In the view of Argand (1911) the Camughera zone represents the southern prolongation and the root zone of his Bernhard nappe, which would correspond to the Mischabel nappe in the present terminology. In this solution the Moncucco zone equals the Monte Leone nappe and is separated from the Camughera zone by the sediments of the "Salarioli-Mulde". Later workers doubted a connection be- tween the Camughera zone and the Mischabel nappe and they regarded Camughera zone and Moncucco zone as one single unit, connected to the Monte Leone nappe, at least in the area of the Bognanco valley (Staub 1937; Bearth 1939, 1956b; Blumenthal 1952). The relationship between the CM unit and the other units within the study area will be discussed below.

\section{Antrona ophiolite complex}

Most of the Antrona ophiolite complex is composed of metabasalts, associated with larger bodies of serpentinites and metagabbros, as well as remnants of metasedimentary cover rocks (Fig. 2). Figure 3 presents a lithostratigraphic profile from Alpe di Oggagia (Fig. 1b), very close to the tectonic contact with the CM unit. From bottom to top serpentinites are followed by metagabbros and metabasalts (amphibolites). Then follows a relatively homogeneous greyish quartz-rich garnet mica schist, overlain by different types of carbonates, reaching from pure marble to calcareous schist. Metapelites, quartz-rich garnet mica schists and bands consisting of metabasalt or metagabbro are interleaved with the carbonates at different levels (Fig. 3). The paleogeographic origin of the Antrona ophiolites (Piemont-Liguria vs. Valaisan) is still a matter of debate (see discussion in e. g. Pfeiffer et al. 1989; Dal Piaz 1999; Keller \& Schmid 2001; Froitzheim 2001; Kramer 2002).

\section{Alpine Deformation history}

The relative timing amongst the individual ductile deformation phases and related structures in the study area largely follows the sequence of four deformation phases described by Milnes et al. (1981) and is mainly based on fold overprinting criteria. However, shearing events are also associated with these distinct folding phases (e.g. Müller 1983; Steck 1984, 1990; Steck \& Hunziker 1994; Mancktelow 1992). Hence, we also used correlations between folding and shearing (Keller \& Schmid 2001) as a basis for establishing the kinematics of the deformation history. The combination of the above mentioned former studies with the results of our study leads to the following Alpine deformation history:

The first deformation phase D1 is associated with a first foliation S1 and contains a stretching lineation X1. This fabric is associated with shear zone formation, isoclinal folds F1 being rare and being observed only within individual tectonic units. Major F1 folds affecting nappe boundaries are not observed or reported. D1 is associated with top-N to top-NW shearing during nappe stacking and starts under eclogite facies conditions within the entire study area (Keller \& Schmid 2001; Keller et al. 2005a).

D2 leads to isoclinal folding (F2) at different scales and under the same kinematic regime as D1 (Keller \& Schmid 2001). Thus, D1 and D2 merely represent progressive stages of the early deformation history, related to nappe stacking. Note, that the major parts of the decompression history are related to nappe stacking. 


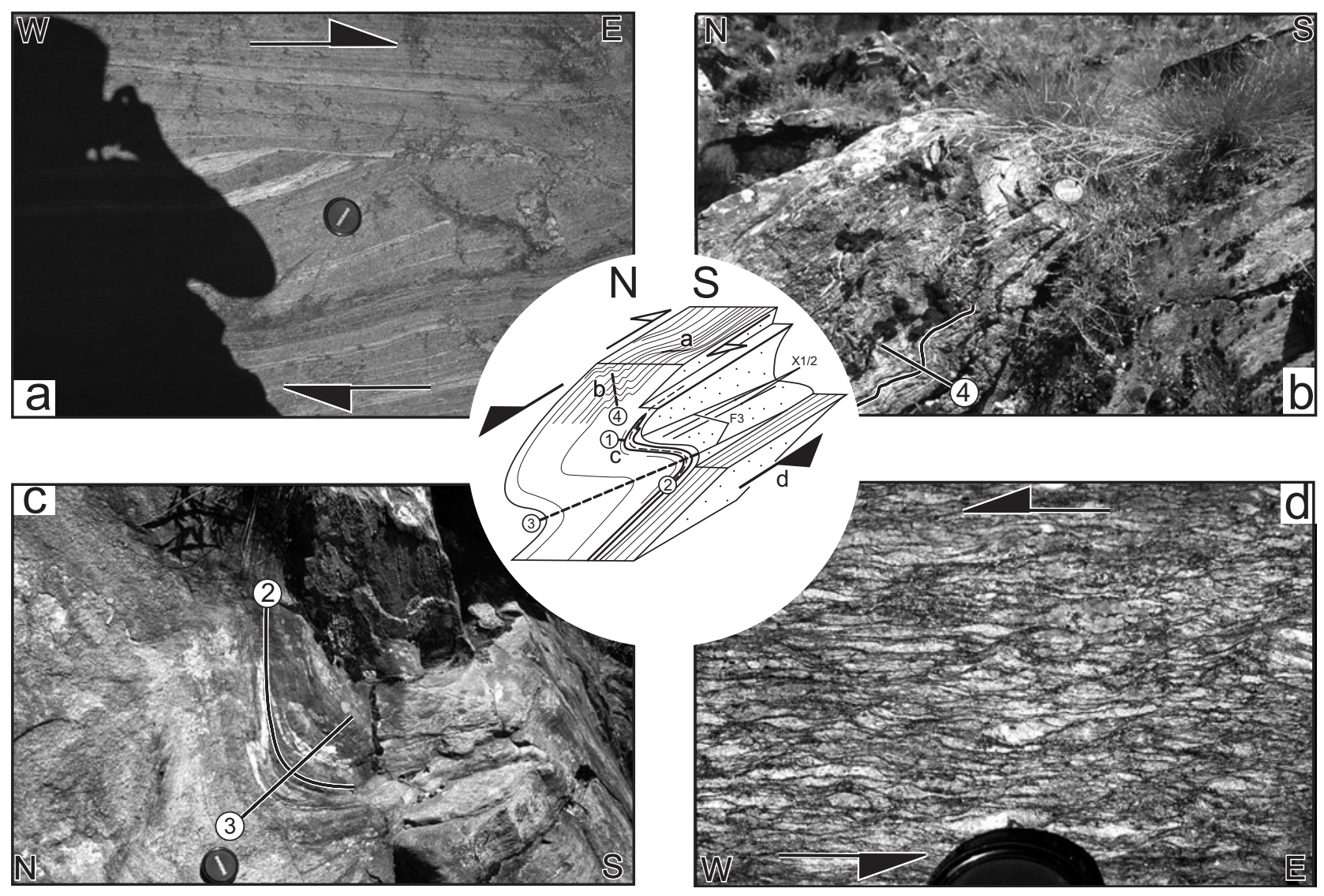

Fig. 4. Outcop-scale structures within the Camughera-Moncucco unit, all from the same outcrop indicated in Fig. 10, synthesised in the sketch in the centre of the Figure. For orientation data at this outcrop, see pole figure of structural elements also given in Figure 10.

a) D1/D2 shear band and oblique boudinage within paragneisses, indicating top-ENE transport.

b) Open chevron-type D4 crenulation within paragneisses.

c) Open D3 fold, overprinting an isoclinal D2 fold within paragneisses. D1 is defined by an earlier foliation S1.

d) D3 shear bands within orthogneiss, indicating top-W transport.

A major switch in the kinematic regime occurred during D3. It led to the formation of a first backfolding phase (D3) with associated shearing: dextral in areas predominated by a subvertical foliation, and top-WSW in flat-lying areas, respectively (Steck 1984; Keller \& Schmid 2001; Kramer 2002).

A subsequent backfolding phase (D4) clearly overprinted D3 (Kramer 2002) and shaped the major Vanzone antiform, whose axial plane crosses the $\mathrm{CM}$ unit. D4 deformation is also associated with dextral shearing, as can be observed in the southern limb of the major D4 Vanzone antiform in the working area. As will be deduced later, the formation of this antiform overlaps in time with normal faulting across the Simplon line.

\section{D1/D2 structures}

The S1/S2 foliation mainly documents shear zone formation during progressive $\mathrm{D} 1 / \mathrm{D} 2$ deformation, associated with the $\mathrm{X} 1 / \mathrm{X} 2$ stretching lineation that indicates original top- $\mathrm{N}$ to top-
NW shearing (Keller \& Schmid 2001). D2 isoclinal folding is merely regarded as a late stage perturbation during progressive D1/D2 deformation, overprinted by two additional folding phases (D3 and D4), both related to backfolding (Fig. 4). S1 is distinct from $\mathrm{S} 2$ only in the hinges of F2 folds, while the transposition of S1 by S2 is complete in F2 fold limbs. Hence the axial planes of $\mathrm{F} 2$ folds are parallel to the main S1/S2 composite foliation. The orientation data for the composite S1/S2 foliation and the D2 folds are presented in Figs. 5 and 6. A major large-scale D2 fold structure was only found in the north of the study area and within the Portjengrat unit (Figs. 2, 7; see also Klein 1978; Milnes et al. 1981 and Keller \& Schmid 2001).

\section{D3 structures and major folds}

During D3 deformation S1/S2 structures as well as nappe boundaries were deformed by open to tight asymmetric similar folds (F3) and by associated shearing (see discussion below). At higher structural levels an S3 axial plane foliation is only 


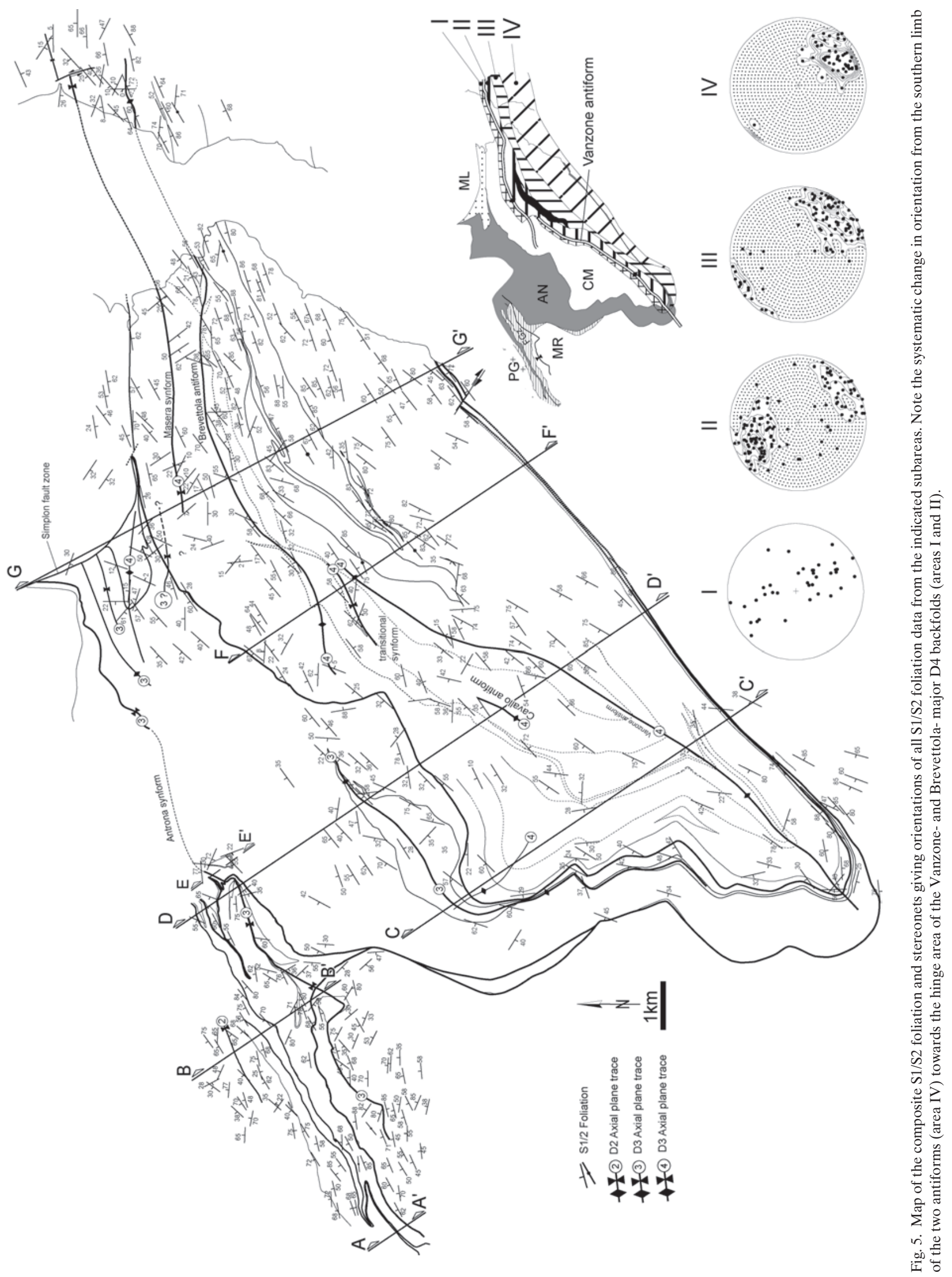




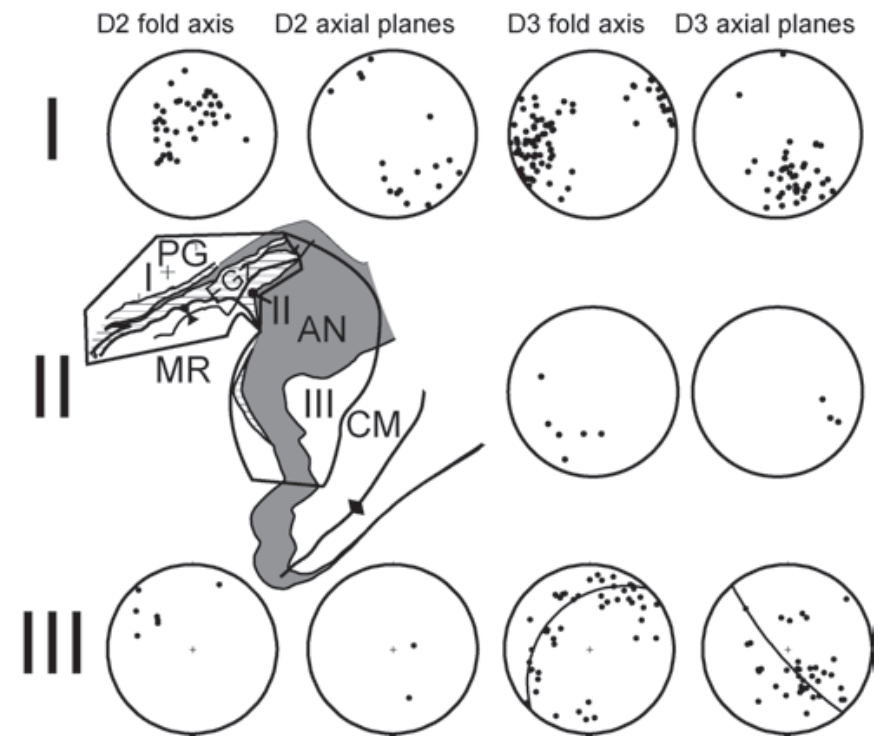

Fig. 6. Orientations of D2 and D3 structural elements (except for stretching lineations and transport directions, given in Fig. 10). There is southwards increase of reorientating D3 axis and D3 axial planes during D4 deformation (compare subarea I and III). Orientation data from subarea I are taken from Keller \& Schmid (2001).

sporadically established (Klein 1978; Keller \& Schmid 2001). Towards deeper structural levels, however, D3 deformation intensity increases and micro-structural observations indicate that the main foliation is the product of the first three deformation phases (S1-S3), hence D3 overprint is more complete (see below). Figure 6 illustrates how the D3 structures change from a more unidirectional distribution in subarea I to great circle distributions in subarea III, indicating progressive overprinting of D3 structural elements by D4 deformation towards the south. The major D3 folds within the study area will now be discussed on the base of the tectonic map (Fig. 2), the main S1/S2 foliation map (Fig. 5), and cross-sections (Fig. 7).

The northern part of the study area exhibits a well-known major D3 synformal structure, the Antrona fold, whose northern limb exposes an overturned D1/D2 nappe stack (Figs. 2, 7) (Klein 1978; Keller \& Schmid 2001). The axial trace of this fold (see Klein 1978 for a more detailed description and mapping of the location of the axial plane trace) runs within the northernmost Monte Rosa nappe in the west (Figs. 2, 7; Klein 1978; Keller \& Schmid 2001; Kramer 2002), enters the Antrona unit towards the east, and finally is cut by the Simplon normal fault in the east (Figs. 2, 7).

A major D3 antiformal fold structure, the Antronapiana antiform, was mapped within the Antrona unit south of the axial plane trace of the Antrona synform, in the vicinity of profile D-D' (Fig. 2). This fold is indicated by the changing asymmetry of parasitic D3 folds, particularly well recognized along profile D-D' of Figure 7. The asymmetry of parasitic D3 folds within the Antrona unit adjacent to the margin with the CM unit points to a continuation of the axial plane trace of the
Antronapiana antiform (Figs. 2, 7). The axial plane trace of the Antronapiana antiform can be followed southwards into a thin prolongation of the main ultramafic body (Fig. 2), and still further south it can be mapped as refolded by the Vanzone antiform (Fig. 2).

Antronapiana antiform and Antrona synform represent a fold pair. According to Klein (1978) and Keller \& Schmid (2001) the nappe stack in southern limb of Antrona synform is in an upright position. This, together with the facing direction of the folded lithostratigraphic ophiolitic sequence of the Antrona unit (Fig. 3, scheme in Fig. 7) suggests that the D3 Antronapiana fold brings parts of Antrona unit into an overturned position. The question whether the D1/D2 tectonic contact between Antrona unit and the CM unit was also inverted during D3 folding, cannot be answered unambiguously. We propose that D3 shearing along the contact between Antrona unit and CM unit only locally overturned the southern limb of the Antronapiana fold, but not the nappe contact (scheme in Fig. 7). Apart from shear indicators (see below) such intense syn-D3 shearing is also evidenced by discordant lithological contacts between rocks derived from the Antrona unit and those derived from CM unit, respectively. Also note, that amphibolites and serpentinites are found again between the overturned top of the sedimentary cover of the ophiolitic sequence below the axial trace of the Antronapiana antiform, and immediately above the contact to the CM unit (Fig. 2).

The original nappe pile, with the Antrona unit being structurally situated above the CM unit, as seen everywhere in the western part of the study area and in the northern flat-lying limb of the D4 Vanzone antiform, however, becomes inverted in the Bognanco valley further to the east. There, along the southern slope of Bognanco valley, i.e. near profile G-G' indicated in Figure 2, the Antrona unit laterally changes into a position structurally below the CM unit in the eastern part of the Bognanco valley. The changeover occurs between profile traces F-F' and G-G' and is indicated in profile G-G' of Fig. 7. This changeover also affects the orientation of the main S1/S2 foliation (Fig. 5), that changes from a dip to the NW in the west to the SE-dip typical for the eastern part of Bognanco valley. This changeover necessitates the existence of a N-closing post-D1/D2 fold with a sub-horizontal axial plane. Such a fold is indeed indicated by the asymmetry of parasitic folds with subhorizontal axial planes, found in the lower limb of this fold, and sketched in profile G-G' of Figure 7. The sub-horizontal axial plane orientation differs from the sub-vertical one of the D4 Masera synform (Fig. 7). Hence, given the lack of D3/D4 overprinting criteria in this area, we favour the interpretation that this fold structure formed during D3 deformation.

An important corollary of the existence of this mega-fold, no matter whether it formed during D3 or D4, is that the Antrona unit appears to have been tightly folded into a structural position below the CM unit, but above the underlying Monte Leone nappe in Bognanco valley. The Monte Leone nappe is commonly regarded as part of a nappe stack with 

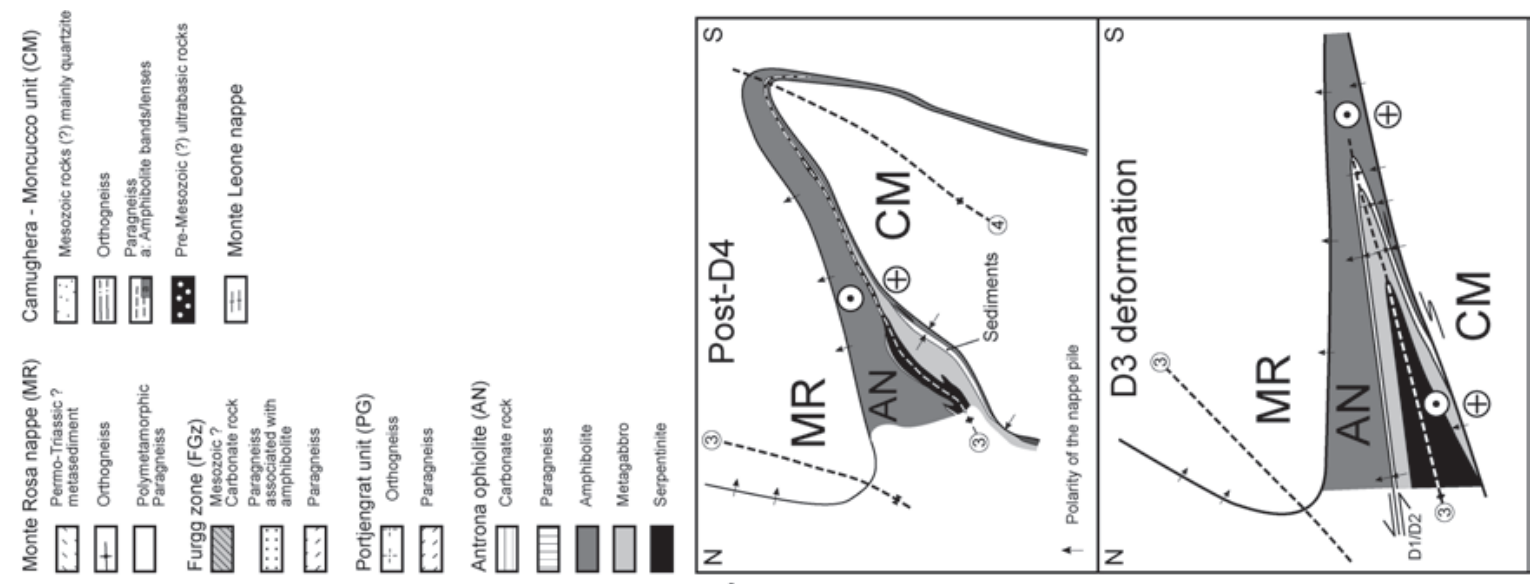



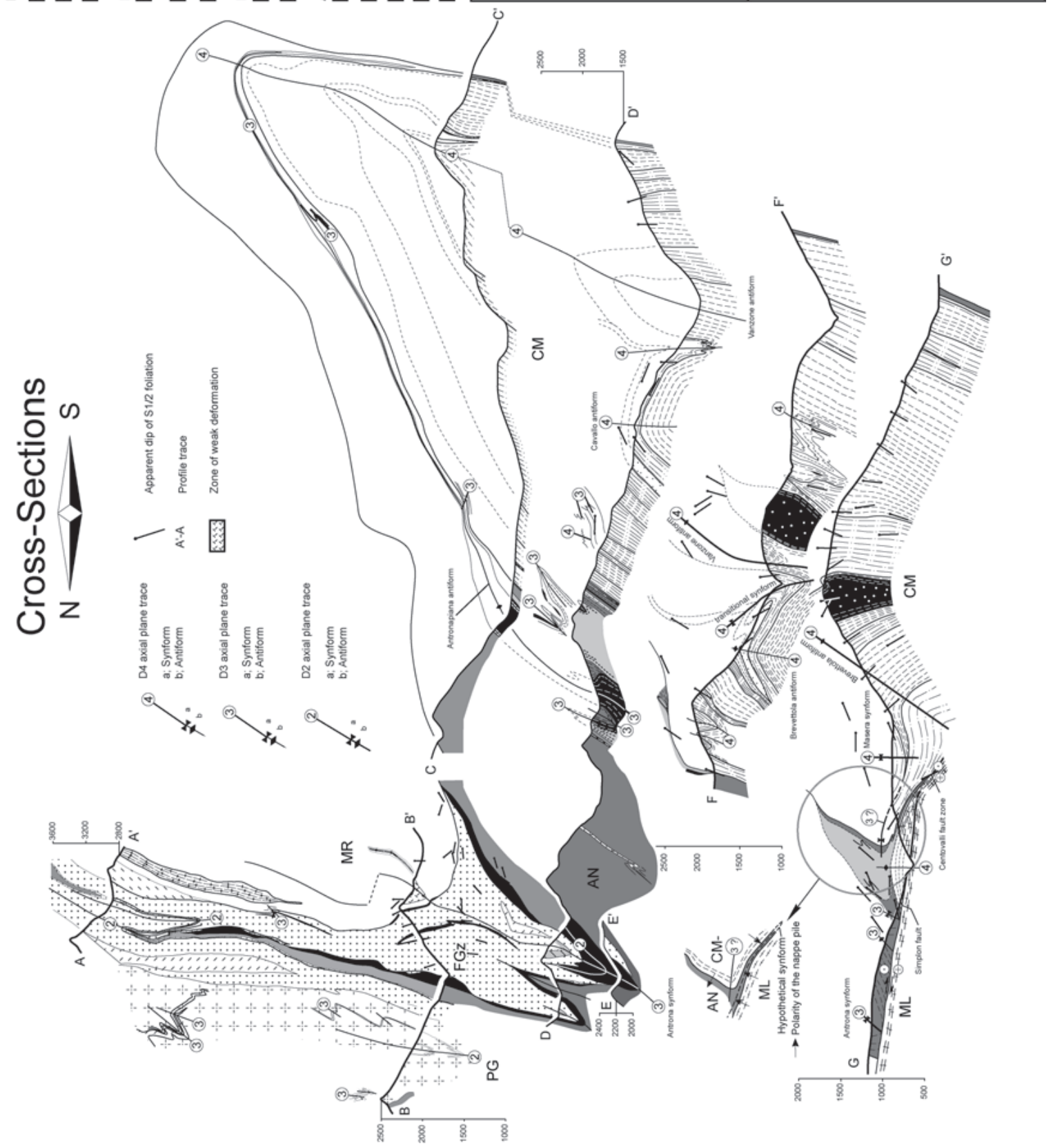

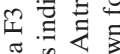

on 0 \&

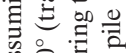

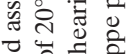

गुण क ज

密合。

흔

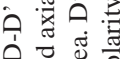

등 总 웅

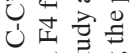

iो of की

中.

话氙

可 总

D

我芯

ن 0

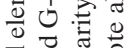

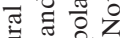

讷吉

50 品

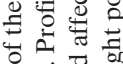

웜응

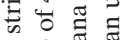

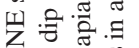

可.

会完完

월

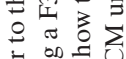

츨 息.

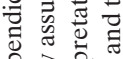

号各过志

言完寻

苞茟哭

峁莒言

U.

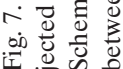


normal polarity, overlain by the Antrona unit (Fig. 7). Hence, given that the nappe polarities indicated in profile G-G' are correct, CM unit and Monte Leone nappe occupy the same original position and have to be connected via a hypothetical synform, which infolds the Antrona unit between those two gneissic units, both attributed to the Sub-Penninic nappe pile derived from the distal European margin (Schmid et al. 2004) (Fig. 7). This solution is in accordance with the proposition of Staub (1937), Bearth (1939, 1956b) and Blumenthal (1952), who also connected the CM unit with the Monte Leone nappe.

\section{D4 structures}

Lithological variations and deformation gradients led to the formation of different types of F4 folds. Open chevron folds, ranging from small-scale crenulations to sizes of tens of meters, predominate in the northern limb of the major Vanzone D4 antiform and at a large distance from its major axial trace. Towards its major axial plane, D4 deformation intensity increases and open similar folds have also been observed. Furthermore, D4 folding is also seen to be associated with dextral shearing, particularly pronounced in the Antrona valley between the localities Ruginenta and Rivera. There, parasitic folds change asymmetry across the major D4 axial plane, while associated dextral shearing does not (see Figs. 8a-c). Slightly west of the locality Sogno (above Villadossola), located in the southern limb of D4 Vanzone antiform, where many D4 folds associated with dextral shearing can be observed, it is evident that D4 folds often nucleate within small-scale dextral D4 shear zones. These shear zones are associated with a sub-horizontal stretching lineation X4. F4 fold axes, which nucleate within such dextral D4 shear zones are often sub-vertical, as can be mainly observed in the southern limb of the Vanzone antiform. In the vicinity of the axial plane and within mica rich schists a new axial planar foliation S4 occasionally develops (Fig. 8e). Overprinting criteria often allow to unambiguously distinguishing between F3 and F4 folds (Fig. 8b, d). In summary, all this evidence indicates that D4 back-folding and dextral shearing is kinematically linked.

\section{Axial traces and kinematic significance of major D4 folds}

\section{The eastern continuation of the major D4 Vanzone antiform within the Camughera-Moncucco unit}

While the location of the axial trace of the Vanzone antiform is unambiguous within the Antrona ophiolitic units, mapping of its eastern continuation remained ambiguous and controversial so far (compare Klein 1978, with Milnes et al. 1981 and Steck et al. 1999, 2001). Remapping of the major D4 structures led to the following results presented with the help of the foliation map (Fig. 5) and interpretative cross-sections (Fig. 7). The hinge of the Vanzone antiform, still well defined at the western termination of the CM unit (Fig. 2) in Anzasca valley (Bearth 1957a; Laduron 1976), enters the Antrona valley at Passo Salarioli. In the floor of the Antrona valley the trace of the major axial plane was mapped between Prato and Rivera (see Figs. 1, 2) based on the changing asymmetry of parasitic folds. Note, however, that a second large-scale D4 antiform, referred to as "Cavallo antiform" (Fig. 2), could also be mapped along a distance of approximately $1 \mathrm{~km}$ along strike further north. Both D4 antiforms are connected by a relatively tight synform, as is indicated by the asymmetry of parasitic D4 fold structures (profile D-D' of Fig. 7).

Further to the northeast the axial plane of the Vanzone antiform was mapped along the southern slope of Testa dei Rossi (Fig. 1), where the major fold hinge is completely exposed. Here the orientation of the main S1/S2 foliation is seen to continuously change from a moderate NW-dip, typical for the northern limb, into a SE-dip indicative for the southern limb near the hinge zone, just before the southern limb becomes recumbent and also turns into NW-dip further to the south. The Vanzone axial plane strikes NE from Testa dei Rossi, entering the Brevettola valley north of a major ultrabasic lens within the Moncucco unit (Figs. 1, 2), where intense D4 folding is observed.

In the upper part of Brevettola valley another F4 antiform first appears, namely the Brevettola antiform (Fig. 2, Klein 1978). There it is seen to affect the orientation of the main S1/S2 foliation. Since there is no evidence for the existence of two antiforms further to the NE, it is concluded that the Brevettola D4 major antiform laterally completely replaces the Vanzone antiform. Only in the upper Brevettola valley, i.e. within a transition zone, are the two antiforms connected by a synform. Possibly, this doubling (Cavallo and Vanzone antiform) of the antiform into two closely spaced hinges is caused by the increased thickness of the CM unit, which here becomes wider than half the wavelength of major D4 folds, thereby locally forcing the formation of an additional major fold.

Still further east, the axial trace of the Brevettola antiform almost turns into an E-W strike (Fig. 2) along the southern slope of the Bognanco valley. Mapping of the axial trace was based on the change in orientation of the S1/S2 foliation from flat lying to steeply SE-dipping in the north to an overturned NW-dip in the south (Figs. 4, 7). Finally, the axial plane of the D4 Brevettola antiform crosses the Ossola valley around Premone (Fig. 2) and reappears in the northern realms of Trontano on the eastern side of the Ossola valley. Just north of the turn of the Brevettola antiform into an approximate E-W strike the northerly adjacent Masera synform, not present further west and described below, starts to appear (Fig. 2).

\section{Major D4 folds mapped in Bognanco valley}

According to Mancktelow (1990), the mylonitic foliation of the top of the Monte Leone nappe, that is part of this Simplon normal fault zone, gradually changes orientation from a SW-dip to a SSE-dip in the area around Fonti di Bognanco (Fig. 5). Note that this change in orientation occurs near the western termi- 

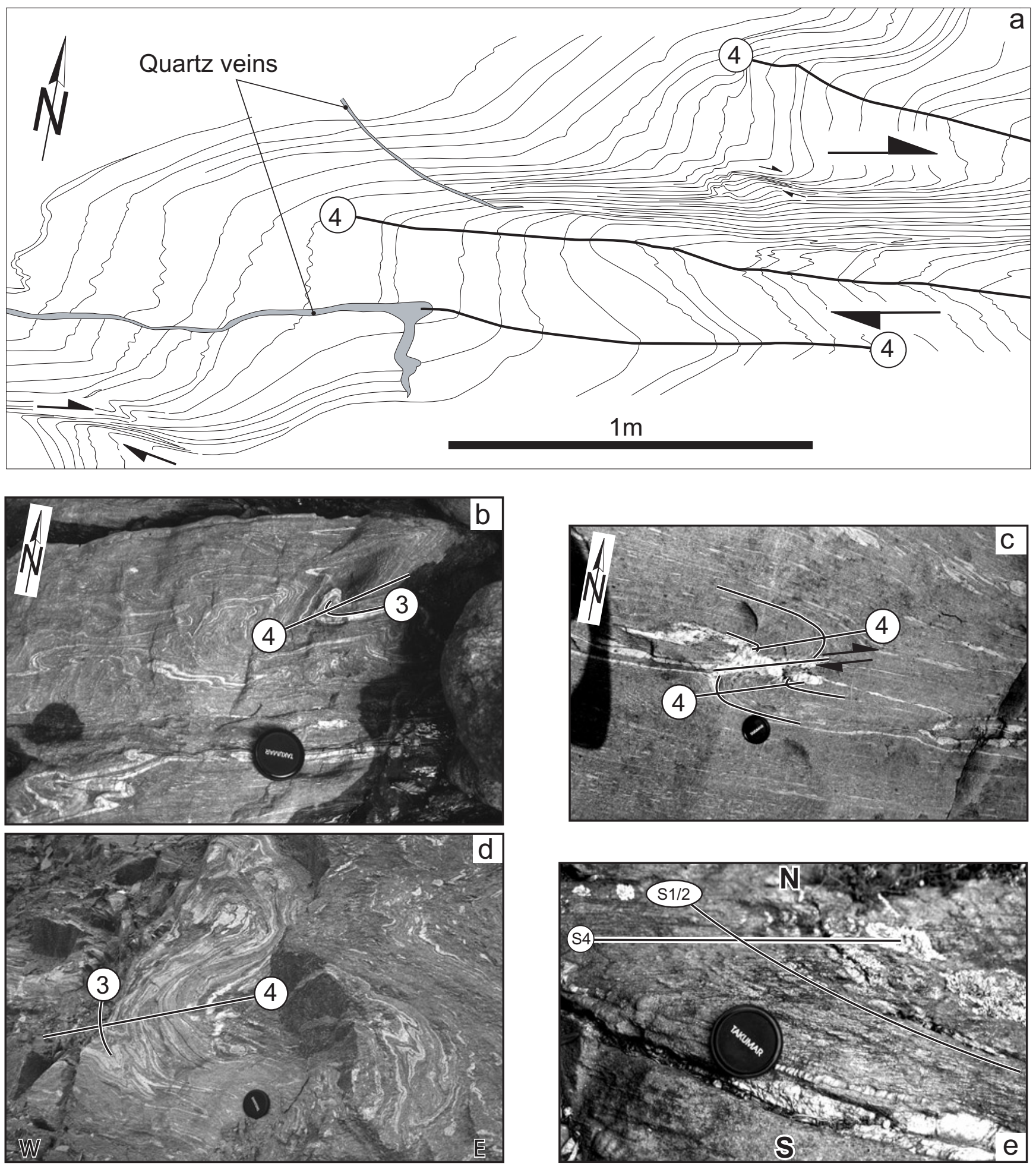

Fig. 8. D4 fold structures within paragneisses from the Camughera-Moncucco unit in Val Antrona. Figure 8a is from north of the axial plane of the Vanzone antiform; Figures 8b, c are from an outcrop situated south of the Vanzone axial plane; Figures 8d, e are situated south of Vanzone axial plane. Note the changing asymmetry of D4 folds across the hinge of the Vanzone antiform, while the sense of shear (Fig. 8a, c) remains the same.

a) Nucleation of the D4 folds evidently being associated with dextral shearing (in map view) and with the injections of quartz veins, which are refolded during later stages of ongoing D4 deformation. b) Overprinting relations between D3 and D4 folds. c) S-type D4 flanking fold (Grasemann \& Stüwe, 2001) around rotated quartz vein, indicating dextral shearing (in map view) during vein formation and D4 folding. d) Overprinting relations between D3 and D4 folds. e) Formation of a new axial planar foliation S4 in the vicinity of the trace of the major axial plane of the Vanzone antiform (in map view). 
nation of the Masera synform, a minor low-amplitude synform (Figs. 2, 5). Also note that the Masera synform bends the main $\mathrm{S} 1 / \mathrm{S} 2$ foliation of the northern CM unit into parallelism with the foliation in the eastern part of the footwall of the Simplon normal fault at the southern rim of the Monte Leone unit. All this strongly suggests a genetic link between the strongly bent eastern continuation of the Simplon normal fault and the Masera synform. Further to the east the axial plane of this synform is found immediately south of Maggianigo (Figs. 1, 2, 5). Finally it crosses onto the eastern side of the Ossola valley, where it corresponds to the "Masera synform" as defined by Milnes et al. (1981).

It is concluded, that D4 deformation on the southern side of the Bognanco valley is characterized by the open MaseraBrevettola synform/antiform pair, oriented parallel to the foliation found at the southern rim of the Monte Leone unit. This fold pair, together with the strongly attenuated eastern continuation of the Antrona ophiolitic unit in lower Bognanco valley, geometrically defines the eastern continuation of the Simplon normal fault (see Fig. 2 and profile G-G' of Fig. 7).

\section{Evidence for dextrally transpressive shearing during D4 deformation}

Approaching the major axial plane of the Vanzone and Brevettola antiforms from the south and perpendicular to the strike of the axial planes, the orientation of the main S1/S2 foliation successively changes from a steep and overturned NWdip to a SE-dip, finally turning into sub-horizontal orientation (Fig. 5). The SW-NE strike and the steep NW-dip in the southern limb of the Vanzone antiform gradually swings around to the WSW-ENE strike seen to both sides of the Ossola valley. This is consistent with the observation that dextral shearing is associated with D4 folding (see previous discussion of Fig. 8). All this suggests that dextral shearing occurs at a large scale within the southern limb of the Vanzone-Brevettola antiform pair. The stretching lineation $\mathrm{X} 4$, associated with this syn-D4 dextral shearing, plunges moderately to the SW in the western part of this southern limb area and changes into a sub-horizontal WSW-ENE orientation further to the E (see orientations of $\mathrm{X} 4$ given in Fig. 10).

The orientation of D4 fold axes also changes laterally (see Fig. 9). A moderate plunge to the SW is observed in the western part of the study area (i. e. subarea V of Fig. 9), while further east (subarea VI of Fig. 9) D4 fold axes often nucleate at dextral shear zones and hence exhibit subvertical to steeply NW or NE dipping fold axis orientations. The fold axes within subarea VI, which are not directly associated with dextral shearing, moderately plunge to the SW. Consequently the orientation of D4 fold axes in subarea VI (Fig. 9) indicates a continuous transition from a near-vertical plunge to moderate SW-plunges that are parallel to the X4 stretching lineations of subarea V (compare Fig. 10). This pattern indicates that F4 fold axes may rotate in a clockwise sense during D4 dextral shearing.
In the northern limb of the Brevettola antiform, and along the Masera-synform, the plunges of D4 fold axes are gentle to subhorizontal. Their strike gradually changes from SW-NE to W-E (Fig. 9). This change in orientation occurs immediately south of the gradational swing in orientation of the Simplon normal fault. It again suggests a direct genetic relationship between D4 folding and normal faulting along the Simplon line.

The D4 fold axial planes (S4) steeply dip to the NW in the southern limb of the Vanzone-Brevettola antiform pair (Fig. 9), also indicating a NW-dip of the above described broad belt that is affected by syn-D4 dextral shearing. However, they steeply dip to the SW in the northern limb of this antiform pair, indicating a convergent fan of axial planes to be associated with large scale D4 folding.

\section{Stretching lineations and change in the kinematics of shearing}

All observed stretching lineations and transport directions are compiled in Figure 10. Transport directions are inferred from macroscopic and microscopic shear indicators (e.g. Simpson \& Schmid 1983). Figure 10 includes orientations of X1/X2 lineations that were refolded by minor D3 folds. Such reorientations of older lineations allow for the construction of movement directions related to D3 folding (Ramsey \& Huber 1987).

Generally, two principally different kinematic regimes can be inferred for the study area. A first kinematic regime is related to D1/D2 mylonitization. Related stretching lineations and associated senses of shear change orientation from place to place, due to intense overprinting during subsequent deformations. The original transport direction during D1/D2 movement was inferred to have been approximately top-N (see extensive discussion in Keller \& Schmid 2001).

The second kinematic regime is related to backfolding during D3 and D4 deformation. In the northern and inverted steep limb of the D3 Antrona backfold this second kinematic regime is characterized by dextral shearing (Fig. 10; Jaboyedoff et al. 1996; Keller \& Schmid 2001). Interestingly, this same transport direction is inferred for subsequent syn-D4 shearing in the southern limb of the D4 Vanzone antiform. This earlier discussed dextral shearing is directly indicated by rotated feldspar porphyroblasts (Fig. 11b). In between these two steep fold limbs, and within the flat-lying nappe stack, this second kinematic regime is characterized by syn-D3 top-WSW orogen-parallel shearing (Figs. 10, 11a). S to WSW directed movements related to D3 backfolding were also deduced from refolded X1/X2 stretching lineations, measured in the same part of the study area (Fig. 10).

Note that, dextral shearing during this second kinematic regime occurs within steeply inclined and overturned portions of the original D1/D2 nappe stack, while top-WSW characterizes the flat-lying and upright parts of this original nappe stack. Also note that D3 top-WSW shearing appears dextral in map view once it becomes rotated into the southern and overturned limb of the D4 Vanzone antiform (Figs. 10, 17b). All this is kinematically consistent with a relative transport of the entire 


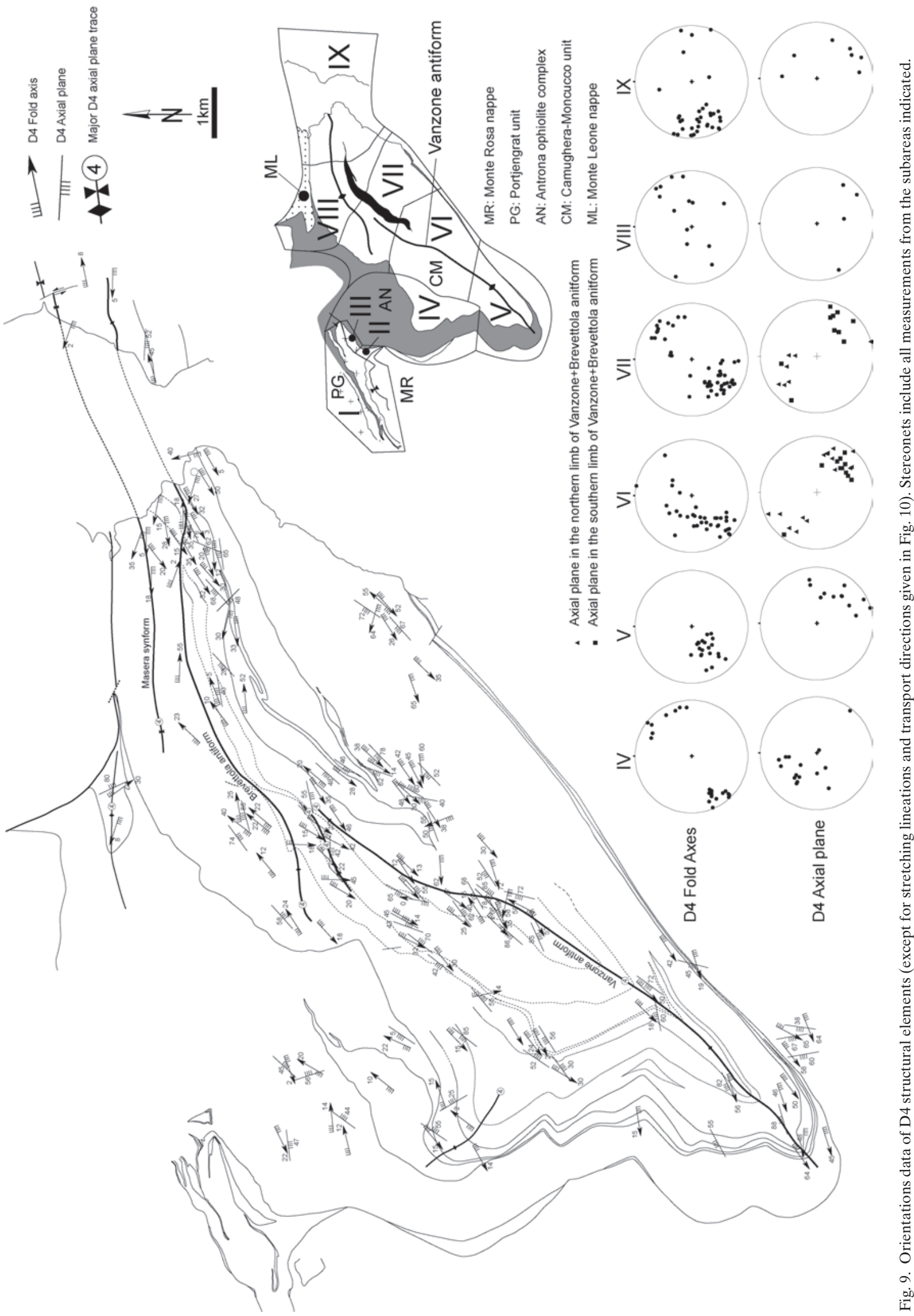




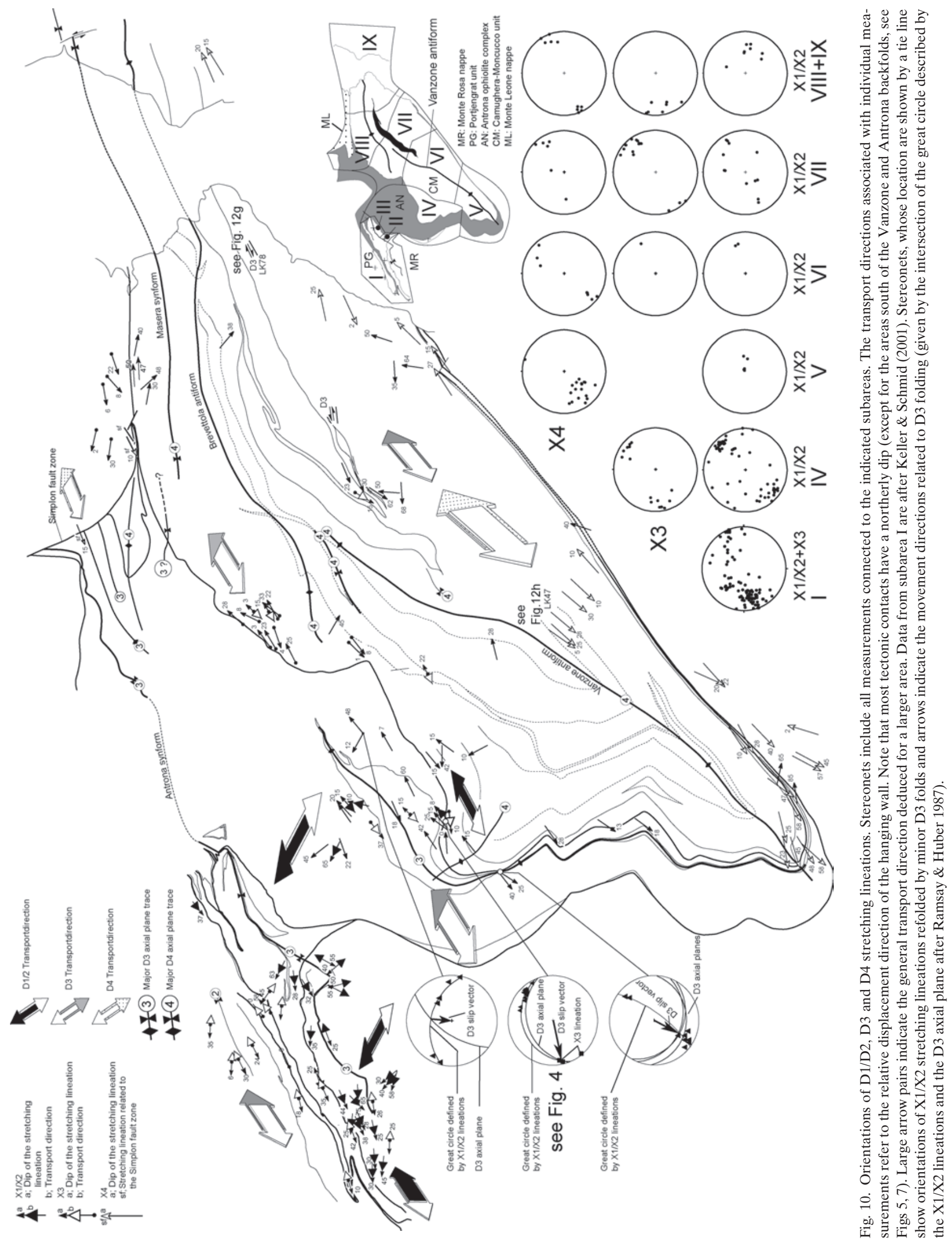



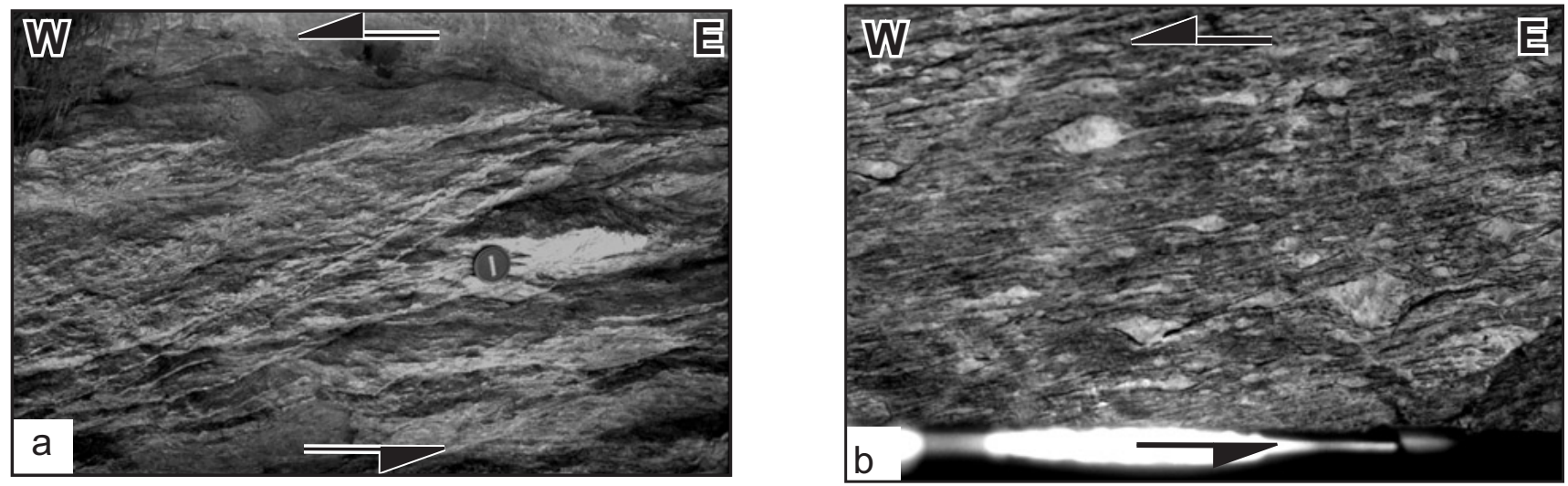

Fig. 11. Illustration of selected transport direction criteria.

a) D3 shear bands, indicating top-WSW transport within metagabbro.

b) D4 $\sigma$-clasts, indicating top-ENE respective dextral transport within orthogneiss of CM unit. Note that the photomicrograph was taken from the bottom to the top, i. e. the opposite of map view.

Monte Rosa nappe towards the WSW during D3 and D4 deformation, and with respect to the deeper structural units exposed in our area of investigation (Fig. 17b).

On a regional scale the reorientation of $\mathrm{X} 1 / \mathrm{X} 2$ stretching lineations is expected to be particularly strong within inverted limbs of major backfolds. In the case of the northern rim (or top in profile view) of the Monte Rosa nappe the original top$\mathrm{N}$ D1/D2 transport direction was reoriented into the presently observed orientation of the D1/D2 transport direction which is top-WSW. This reorientation is directly linked to the overturning of the northern limb of the Antrona synform (subarea I in Fig. 10; Keller \& Schmid 2001). The southern limb of the Antrona synform, being in its original position presently often exhibits top-NNW D1/D2 shearing, but top-WSW and top-S shear sense indicators have locally also been observed (subarea I and IV in Fig. 10, see also Keller \& Schmid 2001). The reorientation of X1/X2 stretching lineations measured around small-scale D3 folds indicates a diversification of X1/X2 orientations ranging from an ENE-plunge over a northern plunge to a WSW-plunge (Fig. 10). This range of orientations is in line with the overall pattern of X1/X2 orientations observed in subarea IV of Figure 10, as well as with the one presently observed at the northern rim of the Monte Rosa nappe (subarea I in Fig. 10, see also Keller \& Schmid 2001, their Fig. 12).

We conclude that, although 4 phases of deformation can be defined by superposition criteria, the kinematic regime only dramatically changed once. Top-N nappe stacking during progressive D1/D2 was followed by a regime of back-folding during D3/D4, formed in a dextrally transpressive regime and associated with the relative top-WSW movement of higher over lower structural units in the flat-lying parts of the D1/D2 nappe stack. This second kinematic regime involved an orogen-parallel stretch and shaped the "Simplon ductile shear zone" as defined by Steck (1990), denoting the totality of dextral movements which were initially distributed within an approximately $10 \mathrm{~km}$ thick deformation zone. This deformation zone shaped the arc of the Western Alps by WNW-directed indentation of the Adria microplate (Schmid \& Kissling 2000; Ceriani et al. 2001).

\section{Late stage Brittle deformation associated with the Centovalli fault zone}

Brittle deformation associated to the Centovalli fault zone, an about $2 \mathrm{~km}$ wide zone of intense brittle deformation, can be found in the Vigezzo valley. Within and south of the mouth of the Vigezzo valley and along the eastern flank of Ossola valley, brittle deformation structures associated with the Centovalli fault zone are clearly seen to post-date and overprint D4 folds, including the fold hinge of the Brevettola antiform. Dextral offset on fault planes predominates, but a map scale sinistral offset of the Masera synform along an antithetic R2 brittle Riedel shear could also be mapped (eastern margin of Fig. 2). Westwards and across the Ossola valley brittle deformation becomes less intense and follows the river Bogna along the valley floor of lower Val Bognanco. In the area around Fonti di Bognanco in Val Bognanco a branch of brittle deformation follows the river Bogna uphill, i. e. towards the west into the upper Val Bognanco, whereas another branch is associated to the brittle deformation in the hanging wall of the Simplon normal fault (Bearth 1956b).

\section{Early stages of metamorphism related to top- $\mathrm{N}$ nappe stacking during D1/D2 deformation}

The early Alpine deformation history is particularly well documented by a anastomosing top-WSW (D1/D2) shear zone from the top of Monte Rosa nappe, situated in the northern limb of the D3 Antrona synform (Keller \& Schmid 2001). Keller et al. (2004) provide a detailed study of this shear zone, which documents the high-pressure overprint of pre-Alpine metamorphic pelites during an early stage of D1/D2 deforma- 

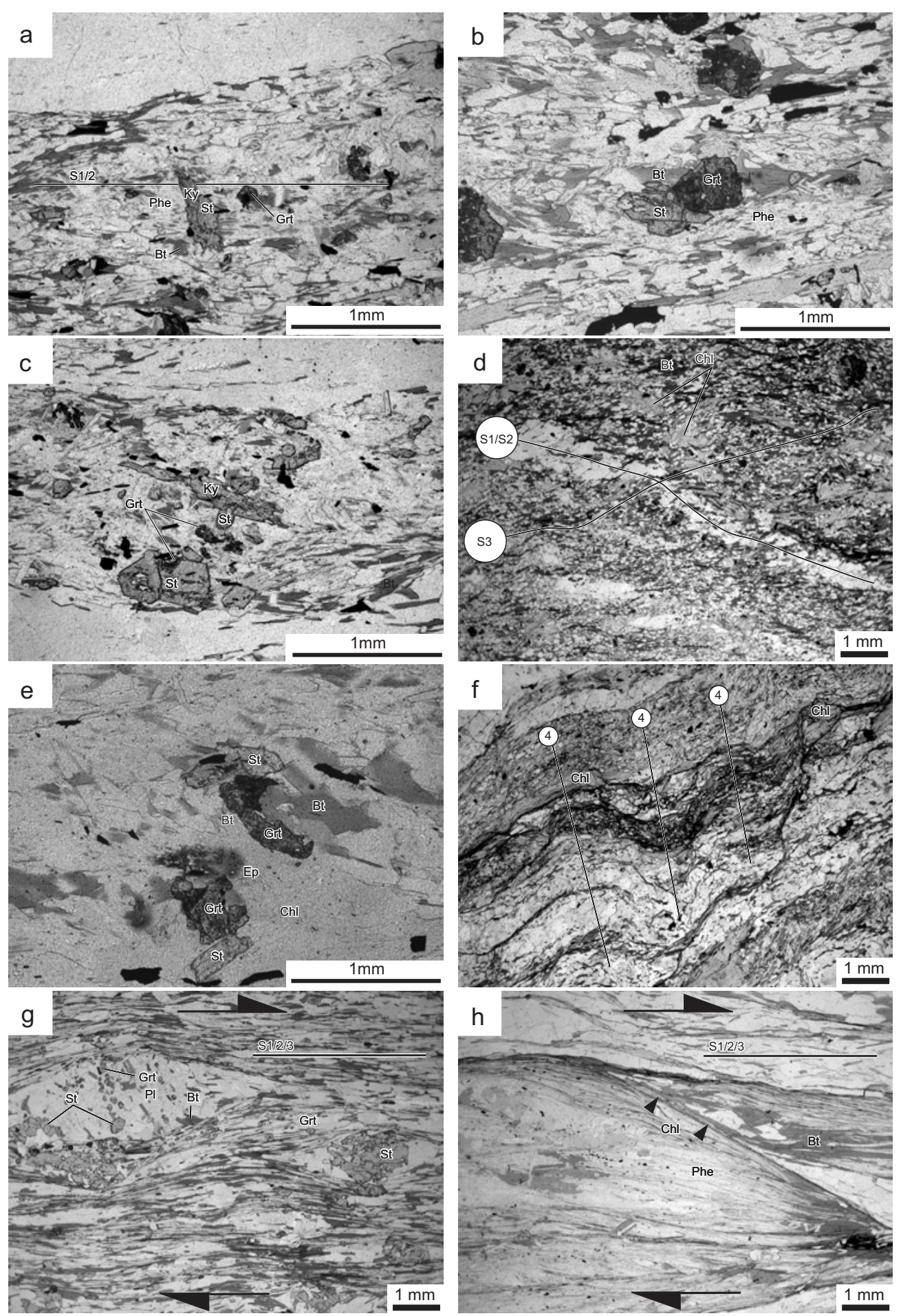

Fig. 12. Photomicrographs of thin sections. Microstructures depicted in Fig. 12a-e are all from the same outcrop illustrated in Figure 4. For the location of Figure 12g, h see Fig. 10.

a) Kyanite and staurolite overgrowing the main $\mathrm{S} 1 / 2$ foliation, defined by phengite, biotite and plagioclase. Staurolite slightly postdates kyanite as it grows at the rim of kyanite. Garnet is strongly corroded. b) Staurolite growing at the rim of garnet and over phengite. Biotite grows in the pressure shadow of garnet and defines the composite S1/2 foliation. c) Staurolite growing at the rim of kyanite and garnet. d) Schistosity S3, defined by biotite (Bt) in fold limbs of D3 folds. Note that chlorite (Chl) shows no preferred orientation. e) Chlorite growing statically at the rims of garnet, staurolite and bioite. Epidote is associated with chlorite. f) Chlorite, refolded by D4 folds. g) Staurolite and plagioclase as porphyroclasts with asymmetric augen structures within the S1/2/3 foliation plane. Asymmetric augen structures indicate D3 dextral shearing in map view. h) Shear bands marked by chlorite, which also grows along biotite likely indicate dextral shearing during D4 in map view. 
tion. In the central parts of the shear zone the Alpine metamorphic overprint is complete and the $\mathrm{S} 1$ foliation is mainly composed of Grt + Phe + Pg + Qtz. The P-T conditions for this transformation are estimated at around $650^{\circ} \mathrm{C}$ at $12.5 \mathrm{kbar}$. For the chemistry of the minerals, related to this early syn-D1 stage of Alpine metamorphism in the Monte Rosa nappe, the reader is referred to Keller et al. (2004). Radiometric age estimates on micas corresponding to the syn-D1 stage will be given later when discussing the timing of Alpine structures.

Within metapelites from the CM unit the assemblage Grt + $\mathrm{Phe}+\mathrm{Pg}+\mathrm{Qtz}$ is again found to represent a first metamorphic stage, documenting peak metamorphic conditions of pressure and temperature within 12.5-16 kbar and $620-700^{\circ} \mathrm{C}$ (Keller et al. 2005a). Hence, the early (D1) formed Alpine mineral assemblage Grt $+\mathrm{Phe}+\mathrm{Pg}+\mathrm{Qtz}$ is identical with that found in the eastern and deeper parts of Monte Rosa nappe (Keller et al. 2004; Keller 2004). Thus, it is concluded that S1 is formed during peak metamorphic conditions and at the same P-T conditions within the CM unit and the eastern and deeper parts of the Monte Rosa nappe contemporaneous with progressive nappe stacking. The ongoing D1/D2 deformation, however, is linked to decompression.

\section{Correlation between polyphase deformation and metamorphism}

In order to establish correlations between individual phases of deformation and metamorphism we selected an outcrop, where overprinting relations of deformation phases are particularly well recognized (Fig. 4). This outcrop is located within the staurolite mineral zone of the Camughera-Moncucco metapelites (Fig. 1). Details concerning mineral assemblages, mineral compositions and bulk rock composition of the metapelites at this outcrop are reported in (Keller et al. 2005a, their sample LK13). Here, we address the correlation between mineral assemblages and different deformation phases.

Figure 4 (centre) depicts a composite sketch of all the deformation features observed at this outcrop. Folding phases (F2, F3 and F4) are seen to overprint the early S1 foliation (Fig. 4). Two generations of stretching lineations and associated shear sense indicators are also present. X1/X2 represents an older stretching lineation and is overprinted by D3 folding, whereby the angle between X1/X2 and the F3 fold axis is quite small. However, a small systematic spread of $\mathrm{X} 1 / \mathrm{X} 2$ orientations around the $\mathrm{F} 3$ fold hinge is still observable (see stereoplot labelled "see Fig. 4" in Fig. 10). X1/X2 lineations presently dip moderately to between $\mathrm{E}$ and NE. Larger systematic spreads of $\mathrm{X} 1 / \mathrm{X} 2$ orientations around F3 fold hinges are observed at other outcrops (Fig. 10). Asymmetric boudinage, probably related to the X1/X2 stretching lineation, presently indicates top-ENE D1/D2 transport direction of the hanging wall (Fig. 4a). A second and younger stretching lineation plunges slightly to the west and is associated with shear bands indicating top-W transport (Fig. 4d). This later sense of shearing and associated stretching lin- eation X3 is correlated to D3 folding because the same kinematic regime is also observed in the overturned limb of the megascopic D3 Antrona synform, interpreted to have formed by shearing during D3 folding (Jaboyedoff et al. 1996; Keller \& Schmid 2001). The great circle defined by the refolded $\mathrm{X} 1 / \mathrm{X} 2$ stretching lineation intersects the axial plane of the corresponding D3 fold, and the intersection dips gently to the west, giving the movement direction related to D3 folding (Ramsay \& Huber 1987). Hence, the D3 movement directions inferred from refolded $\mathrm{X} 1 / \mathrm{X} 2$ stretching lineations is similar to the orientation of X3, which supports the interpretation of top-W shearing during D3 deformation at this outcrop. Note, however, that the angle between the constructed great circles is quite small causing their intersection to be affected by small angular variance.

The main S1/S2 foliation is well preserved in metapelite sample LK13, which contains garnet, phengite, biotite, kyanite, staurolite, plagioclase, chlorite, epidote as major minerals and opaque minerals. Garnet, phengite, plagioclase and biotite define the S1/S2 foliation. Paragonite occurs as relict inclusions in garnet and plagioclase. Its disappearance is related to ongoing decompression (see later discussion of Fig. 13). Staurolite grows at the rim of kyanite. Staurolite and kyanite grew under static conditions since they postdate the formation of the main S1/S2 foliation (Fig. 12a, c). Garnet is inferred to have decomposed in order to form staurolite. This is based on the observation that garnet predates staurolite, overgrowing the rim of garnets (Fig. 12b, c). Chlorite and associated epidote grew as the latest minerals (Fig. 12e). Chlorite overgrows the main $\mathrm{S} 1 / 2$ foliation, its growth nucleating at grain boundaries of preexisting garnet, staurolite and biotite (Fig. 12e). A sample taken from the hinge zone of a D3 fold reveals that the S3 axial plane foliation is predominantly defined by bioite, indicating its growth during D3 deformation (Fig. 12d). In this specimen chlorite is seen to also overgrow the S3 foliation (Fig. 12d). Staurolite is found to be stable in D3 fold hinges and hence interpreted to have grown during D3. Apart from this outcrop staurolite is stable during intense D3 deformation, as it defines the foliation in the deeper structural parts, where the foliation is a composite one, formed during the first three deformation phases (see below). Yet another sample, taken from the hinge zone of a D4 fold, shows that D4 folding postdates the formation of chlorite, which is folded during D4 deformation (Fig. 12f).

Figure 13a shows the equilibrium diagram calculated in the system KNCFMASH for the bulk rock composition of the Alpoor metapelitic sample LK13 (see Keller et al. 2005a) and serves as a basis for discussing the P-T evolution associated with progressive deformation. The grey shaded area marks peak P-T conditions of metapelites from the study area. This P-T area is defined by the overlap of two stability fields of first stage assemblages (Keller et al. 2005a). Within errors this P-Tarea is compatible with the indication that maximum pressure is likely to range between $14.5 \mathrm{kbar}$ and $16 \mathrm{kbar}$ (black dots in Fig. 13a), derived from a comparison of calculated end- 

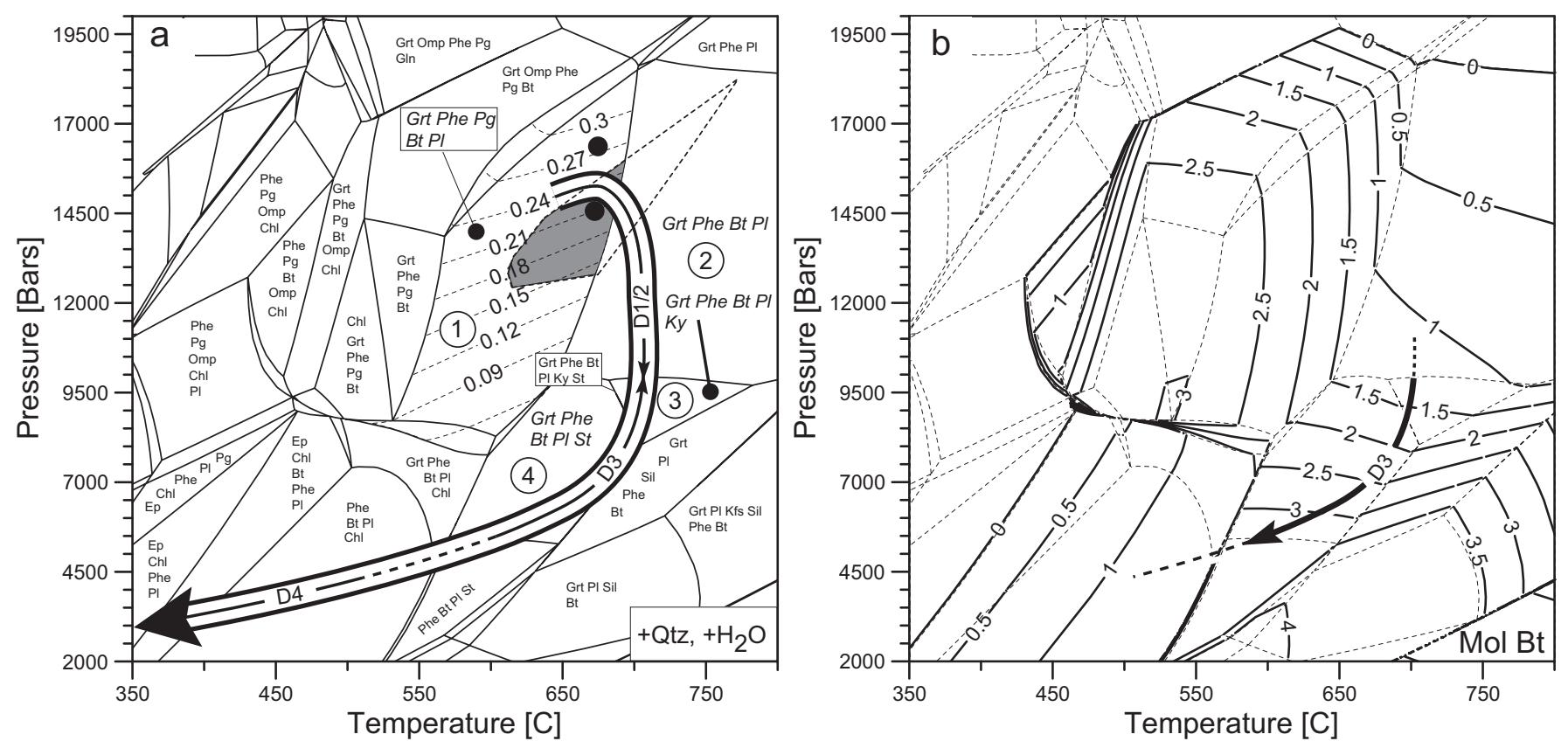

Fig. 13. Equilibrium phase diagrams for the measured bulk rock chemistry of the CM metapelitic sample LK13 taken from the outcrop depicted in Figure 4 (compare micrographs given in Figure 12a-e). The diagrams are calculated with the program DOMINO (De Capitani 1994) and they postulate distinct stable phase assemblages and corresponding mineral composition based on thermodynamic properties defined in the database (JUN92). Bulk rock chemistry is determined by powder $\mathrm{X}$-ray diffraction and normalized to 100 cations, all iron is taken as $\mathrm{Fe}^{2+}$.

a) Equilibrium phase diagram for the specific bulk rock chemistry of sample LK 13, illustrating the stable mineral assemblages and the proposed P-T-d loop. Water and quartz are stable with all mineral assemblages indicated. Numbers 1, 2, 3, 4 refer to mineral parageneses of sample LK13 discussed in the text. Stippled contours give the calculated Mg-Celadonite content in phengite. Black dots without tie lines indicate the measured $\mathrm{X}_{\mathrm{Mg} \text {-Cel }}$ in the cores of phengite. Grey shaded area indicates peak P-T conditions after Keller et al. (2004) and is defined by the overlap of two first stage assemblages from metapelites with different bulk rock composition.

b) Mineral abundance isopleths of biotite. The diagram is calculated for the measured bulk rock chemistry of sample LK13 with the program DOMINO (De Capitani 1994). The postulated isopleths are given in moles of a stable phase based on the thermodynamic properties defined in the database (JUN92). Bulk rock chemistry is determined by powder $\mathrm{X}$-ray diffraction and normalized to 100 cations while all iron is taken as $\mathrm{Fe}^{2+}$.

member isopleths of $\mathrm{MgCel}$ with measured $\mathrm{X}_{\mathrm{MgCel}}$ in phengite cores $(0.21$ to 0.28$)$.

The P-T conditions of ongoing D1/D2 deformation are reflected by the stability fields of the assemblages $\mathrm{Grt}+\mathrm{Phe}+\mathrm{Pg}$ $+\mathrm{Pl}+\mathrm{Bt}+\mathrm{Qtz}$, later replaced by $\mathrm{Grt}+\mathrm{Phe}+\mathrm{Pl}+\mathrm{Bt}+\mathrm{Qtz}$, as paragonite disappears in the matrix during decompression (assemblages 1 and 2 in Fig. 13a). Note, that the stability limit of $\mathrm{Pl}$ and $\mathrm{Bt}$ depends on the P-T conditions, but also on bulk rock chemistry. In Al-poor metapelites, such as described here, $\mathrm{Pl}$ and Bt may be stable towards higher pressures than in Al-rich metapelites (Nagel et al. 2002; Keller et al. 2005a). Both assemblages compose the main S1/S2 foliation that obviously formed during a first stage of progressive decompression. The P-T field related to D1/D2 deformation is limited towards lower pressures of around $10 \mathrm{kbar}$ by the stability fields of kyanite and staurolite (assemblages 3 and 4 in Fig. 13), since both these minerals overgrow the main $\mathrm{S} 1 / 2$ foliation in specimen LK 13.

The assemblages Grt $+\mathrm{Phe}+\mathrm{Pl}+\mathrm{Bt}+\mathrm{Ky}+\mathrm{Qtz}$ and $\mathrm{Grt}+$ $\mathrm{Phe}+\mathrm{Pl}+\mathrm{Bt}+\mathrm{St}+\mathrm{Qtz}$ are correctly predicted by the phase diagram of Fig. 13a (assemblages 3 and 4). The calculated subhorizontally oriented mineral abundance isopleths predict the growth of biotite within the stability field of the former two assemblages during further decompression (Fig. 13b). Since this is in accordance with the observation that substantial amounts of biotite grows during D3 folding, we conclude that the assemblages 3 and 4 depicted in Figure 13a indeed reflect the P$\mathrm{T}$ conditions of D3 deformation. For the CM unit Klein (1978) also suggested the formation of biotite during D3 folding (his D2). Towards lower pressures the assemblage $\mathrm{Grt}+\mathrm{Phe}+\mathrm{Pl}+$ $\mathrm{Bt}+\mathrm{Ky}+\mathrm{Qtz}$ is limited by the predicted disappearance of kyanite and the growth of staurolite that only coexists in a very narrow P-T interval with kyanite (Fig. 13a). Formation of staurolite at the expense of kyanite is indeed observed during decompression, as was discussed earlier (Fig. 12a, c). In sample LK13 this former replacement is far from complete. This is interpreted to be due to sluggish replacement of kyanite by staurolite for kinetic reasons when sample LK 13 underwent ongoing syn-D3 retrogression through the P-T area defined by the assemblage 4 (Fig. 13a), where kyanite can only be metastable. Since LK 13 and surrounding metapelites are devoid of sillimanite, the P-T conditions inferred for D3 are limited towards lower pressures by the stability fields, which involve the 


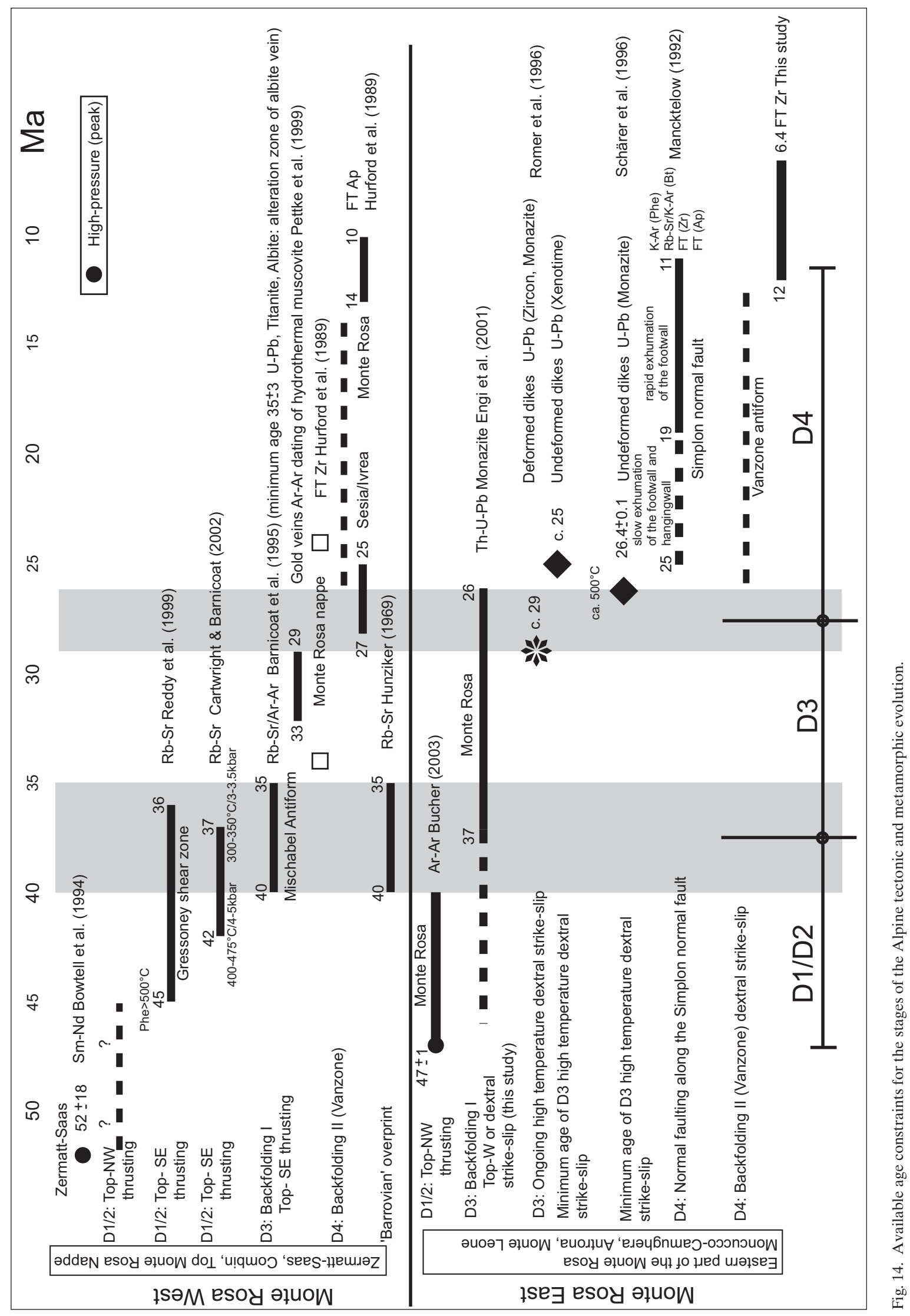


growth of sillimanite (Fig. 13a). This indicates that the rocks must have started to cool in the course of ongoing syn-D3 decompression. Because chlorite flakes are seen to overgrow the S3 axial plane foliation, and at the same time the previously formed staurolite (Fig. 12e), we take the stability field of assemblage $4(\mathrm{Grt}+\mathrm{Phe}+\mathrm{Pl}+\mathrm{Bt}+\mathrm{St}+\mathrm{Qtz})$ to limit D3 deformation towards lower temperatures. Stability of chlorite at the expense of staurolite is expected to set in at around $570^{\circ} \mathrm{C}$ and 5.5 kbar (Fig. 13a), i.e. the P-T conditions suggested for the termination of D3 deformation.

During further retrogression chlorite is expected to grow at the expense of staurolite, garnet and biotite. According to Fig. 13a the decomposition of staurolite and garnet should theoretically progresses to completion as assemblage $\mathrm{Grt}+\mathrm{Phe}+\mathrm{Pl}+$ $\mathrm{Bt}+\mathrm{Chl}+\mathrm{Qtz}$ becomes stable. This is not observed, again for kinetic reasons (slow decomposition progress of garnet and staurolite), these two minerals remaining metastable. The postulate that D4 deformation is likely to immediately follow the termination of $\mathrm{D} 3\left(\mathrm{P}<\mathrm{c} .5 .5 \mathrm{kbar}, \mathrm{T}<\mathrm{c} .570^{\circ} \mathrm{C}\right)$ is indirect but reasonable, given the similar kinematic scenarios for both D3 and D4 discussed earlier. Hence Figure 13a proposes in that further cooling of the metapelites below $570^{\circ} \mathrm{C}$ and down to temperatures of around $280^{\circ} \mathrm{C}$, expected for the brittle-viscous transition of quartz (Stipp et al. 2002), predominantly occurred during D4 deformation.

\section{Tectonic and metamorphic evolution of the working area in a regional context}

For the western part of Monte Rosa nappe Chopin \& Monié (1984) derived P-T conditions for the high-pressure stage of 16 kbar at $500^{\circ} \mathrm{C}$. For this part of the Monte Rosa nappe Dal Piaz \& Lombardo (1986) derived pressures in the range between 8-10 kbar and $<14 \mathrm{kbar}$, at temperatures of $440^{\circ} \mathrm{C}-530^{\circ} \mathrm{C}$. Borghi et al. (1996) derived P-T estimates in the range of $518-546^{\circ} \mathrm{C}$ at $11-14 \mathrm{kbar}$ for an earliest Alpine mineral assemblage containing $\mathrm{Grt}+\mathrm{Cld}+\mathrm{Chl}$ from a pelitic sample from this same area. Based on the published P-T estimates derived from pelitic rocks we propose that the P-T conditions for the high-pressure stage of the western part of the Monte Rosa nappe probably were in the range of $500-550^{\circ} \mathrm{C}$ at $14-16 \mathrm{kbar}$, the lower pressures obtained by Borghi et al. (1996) probably indicating early stages of decompression.

Within the structurally lower units exposed further east, which include the Antrona ophiolites, the CM unit and the eastern and deeper parts of the Monte Rosa nappe, higher temperatures at almost identical pressures are indicated to have prevailed during the high-pressure stage. For Antrona ophiolites a minimum pressure around 14-16 kbars at $480-720^{\circ} \mathrm{C}$ was obtained (Colombi \& Pfeifer 1986). The CM unit and the eastern and deeper parts of the Monte Rosa nappe reached P-T conditions of about 12.5-16 kbar at $620-700^{\circ} \mathrm{C}$ during the high-pressure stage (Fig. 13 and Keller et al. 2005a; Keller et al. 2004, see also discussion). Note however, that the area under consideration additionally exhibits a
"Barrovian-type" metamorphic field gradient, which is characterized by an eastward and downward increase in temperatures (Bearth 1958; Colombi 1989; Frey et al. 1974, 1999). Hence the temperature differences between west and east described above must have persisted at lower pressures during the later stages of metamorphism. In theory, these temperature differences related to 'Barrovian-type metamorphism' could be entirely inherited from the precursory high-pressure stage (see discussion). Indeed, decompression is near-isothermal in the more eastern and structurally deeper parts of the study area, where sillimanite grade at about $650^{\circ} \mathrm{C}$ and $5 \mathrm{kbar}$ is reached during decompression (Keller et al. 2005a). Note that this is not the case in the structurally higher units in the west (e.g. Borghi et al. 1996).

The relatively high temperatures at low pressures in the eastern part of the study area are reached during D3 deformation (Fig. 13a). D3 exhibits a NE-SW oriented and orogen-parallel extensional component, characterized by top-WSW, respectively dextral shearing. Because of this syn-D3 component of extensional unroofing, and following Thompson \& England (1984), it is proposed that exhumation during D3 deformation progresses much faster in the deeper structural units (i.e. the $\mathrm{CM}$ unit) than could be achieved by erosion only.

D3 deformation within the staurolite mineral zone occurs over a considerable P-T interval, where the continuous decomposition of phengite forms biotite, staurolite and plagioclase within a wide range of metapelitic compositions (Keller et al. 2005a). Hence, overprinting in the course of ongoing D3 folding and shearing may progress to completion, thereby causing the main foliation to be a composite foliation formed during the first three deformation phases D1 to D3. Indeed it was frequently observed that staurolite and plagioclase are host porphyroclasts of asymmetric augen structures within the foliation plane in the more eastern parts of the study area, thus defining such a composite main foliation (Fig. 12g). Hence, D3 deformation appears to be more pervasive within deeper structural levels. Within the southern limb of the Vanzone antiform such asymmetric augen structures often indicate dextral shearing. Hence, it is suggested that the main foliation in the eastern area to both sides of the Ossola valley is a composite one formed during the first three deformation phases. Many D3 top-WSW shear indicators may have been passively rotated into the southern limb of the D4 Vanzone antiform where they would appear dextral in map view.

There are also shear bands marked by chlorite, which grows at the grain boundaries of biotite (Fig. 12h). Such observations likely indicate the decomposition of biotite during ongoing retrogression and dextral shearing during the D4 deformation, which is characterized by a very similar kinematic scenario, as was previously discussed.

Overprinting criteria, orientation data of structural elements and correlation between metamorphism and deformation all indicate that the overprinting of the first backfolding phase (D3) by the second backfolding phase (D4) occurred at 
lower temperatures compared to those prevailing during D3 deformation. D4 deformation definitely postdates the formation of staurolite. Hence, on a regional scale the relative timing between staurolite growth and D4 deformation is documented by the folded outline of the staurolite mineral zone boundary (Fig. 1), tracing the major D4 Vanzone antiform.

In summary, the exhumation history may be subdivided into the same two stages that were previously deduced for the kinematics of deformation. During a first stage of D1/D2 nappe stacking decompression is near-isothermal in the working area. The second stage of decompression in the working area is initially associated with a Barrow-type field metamorphic gradient, that is immediately followed by more rapid cooling during ongoing D3 and D4 deformation in a dextrally transpressive scenario, probably due to partial unroofing by an orogen-parallel extensional component of this second kinematic stage.

\section{Chronology of Alpine structures}

Based on selected published radiometric data, which in part directly date deformation phases, we discuss the timing of the tectonic and metamorphic evolution of the study area and surrounding units based on the compilation of data presented in Fig. 14. We also present new fission track data, established for the area along the Ossola valley (Fig. 15, Tab. 1).

\section{Top N-NW thrusting and nappe stacking (D1/D2)}

The first two deformation phases (D1/D2) of the Alpine orogenic cycle are related to top-N nappe stacking in a context of underthrusting of the European plate below the Adriatic margin (e.g. Steck 1984, 1987; Lacassin 1987; Steck \& Hunziker 1994; Schmid \& Kissling 2000). This top-N shearing (top-NW according to some authors) is associated with nappe stacking, which starts under high-pressure metamorphic conditions in the eclogite bearing units and is immediately followed by a first stage of exhumation. Within the working area the formation of the eclogitic part of D1/D2 shear zone from the Monte Rosa nappe (Keller et al. 2004) was dated as $47 \mathrm{Ma}$ (+-1) by ${ }^{39} \mathrm{Ar}-{ }^{40} \mathrm{Ar}$ dating (Bucher 2003). For the Zermatt zone a similar age of $51 \pm 18 \mathrm{Ma}$ is obtained for the high-pressure metamorphic stage by using Sm-Nd dating of garnet (Bowtell et al. 1994). A younger age (c. $44 \mathrm{Ma}$ ) is obtained from SHRIMP dating of zircon (Rubatto et al. 1997).

However, at the structurally highest level exposing eclogite facies units, namely at the southwestern top of the Monte Rosa and Zermatt zone, Rb-Sr dating of the top-SE movement, linked to the Gressoney shear zone, yielded ages that are supposed to date the activity of the Gressoney shear zone, ranging between 45 and $36 \mathrm{Ma}$. These ages are interpreted to also date the timing of exhumation of eclogite facies rocks, attributed to normal faulting along this shear zone (Reddy et al. 1999). Assuming that the interpretation of the $\mathrm{Rb}-\mathrm{Sr}$ isotope ages and associated tectonic inferences are correct, D1/D2 top-N shear- ing and associated high-pressure metamorphism at deeper structural levels, including our working area, would overlap in time with top-SE extensional shearing at structurally higher levels such as the Gressoney shear zone. Hence both the top$\mathrm{SE}$ and the top-N shearing would be related to the exhumation of eclogite facies rocks. This indicates differential ascent of the eclogite facies units with respect to over- and underlying tectonic units. In addition to the Gressoney shear zone, a top- SE extensional stage is also attributed to the Combin fault considered to substantially exhuming eclogite facies rocks (Ballèvre \& Merle 1993). Hence, we speculate that exhumation of the eclogitic rocks in the upper Penninic units occurred by active extrusion within a subduction channel that formed during overall crustal shortening (e. g. Dal Piaz et al. 1972; Chemenda et al. 1997; Engi et al. 2001b; Bucher et al. 2004).

\section{First phase of backfolding (D3)}

In the structurally higher parts, i. e. in the Zermatt area, greenschist facies top-SE backthrusting related to the D3 Mischabel fold gives an age of about $40 \mathrm{Ma}$, dated with ${ }^{40} \mathrm{Ar} /{ }^{39} \mathrm{Ar}$ and $\mathrm{Rb} / \mathrm{Sr}$ data on white micas and amphiboles (Barnicoat et al. 1995). Field relations suggest that albite veins postdate the activity of syn-Mischabel fold shearing, whereby an absolute age of around $35 \mathrm{Ma}(\mathrm{U}-\mathrm{Pb})$ is obtained for vein alteration zones (Barnicoat et al. 1995). Also in the Zermatt area a similar time interval (42-37 Ma) has recently been obtained by $\mathrm{Rb}$-Sr dating of apatite-muscovite pairs for the active stage of greenschist facies top-SE shearing, P-T estimates indicating that shearing started at $400-475^{\circ} \mathrm{C} / 4-5 \mathrm{kbar}$ and terminated at 300-350 ${ }^{\circ} \mathrm{C} / 3-3.5$ kbar (Cartwright \& Barnicoat 2002). Zircon fission track ages (34-24 Ma) from the structural top of the Monte Rosa nappe suggest that these structurally higher parts cooled below c. $250^{\circ} \mathrm{C}$ during early Oligocene times (Hurford et al. 1989, his Fig. 8; Bistacchi et al. 2001). Based on these published data it is suggested that greenschist facies syn-D3 top-SE backthrusting and backfolding started in the late Eocene and terminated in the early Oligocene in these structurally higher parts, immediately following Eocene D1/D2 topNW shearing. Then ductile deformation is followed by Oligocene brittle deformation in these structural higher parts (Bistacchi \& Massironi 2000).

However, in the structurally deeper parts (i.e. the eastern part of the Monte Rosa nappe and CM unit), characterized by top-WSW and dextral shearing, respectively, D3 deformation occurred at significantly higher temperatures (i.e. under Barrovian P-T conditions). For the Monte Rosa nappe Engi et al. (2001a) provide monazite ages, interpreted by the authors to date an early stage during decompression, ranging between 38 and $32 \mathrm{Ma}$ ago. However, the ages obtained for monazites from staurolite and sillimanite bearing metapelitic samples (sample Bi9801 and Po9703 of Engi et al. 2001a, their Fig. 3) from the eastern part of the Monte Rosa nappe range between 37 and $26 \mathrm{Ma}$ and are interpreted to date different re-equilibration stages during decompression. These Barrovian P-T 
Tab. 1. Zircon (Z) and apatite (A) fission track ages

\begin{tabular}{|c|c|c|c|c|c|c|c|c|c|c|}
\hline Samples & Altitude [m] & $\mathrm{N}$ & $\mathrm{N}_{\mathrm{s}}$ & $\mathrm{N}_{\mathrm{i}}$ & $\mathrm{r}_{\mathrm{s}}\left[10^{4} \mathrm{~cm}^{-2}\right]$ & $\mathrm{r}_{\mathrm{i}}\left[10^{4} \mathrm{~cm}^{-2}\right]$ & $\mathrm{r}_{\mathrm{d}}\left[10^{4} \mathrm{~cm}^{-2}\right]$ & $\mathrm{N}_{\mathrm{d}}$ & $\mathrm{P}\left(\mathrm{c}^{2}\right)[\%]$ & Age $\pm 2 s[\mathrm{Ma}]$ \\
\hline MH11/00 A & 450 & 30 & 26 & 1516 & 16.20 & 946.9 & 799 & 7700 & 99.43 & $2.4 \pm 1.0$ \\
\hline MH11/00 Z & 450 & 12 & 404 & 1611 & 1561 & 6224.8 & 379 & 2679 & 33.66 & $5.4 \pm 1.4$ \\
\hline $\mathrm{MH} 12 / 00 \mathrm{~A}$ & 400 & 10 & 36 & 1368 & 131 & 4978.8 & 849 & 7700 & 89.07 & $3.9 \pm 1.4$ \\
\hline MH12/00 Z & 400 & 4 & 97 & 285 & 2623.6 & 7708.5 & 325 & 2679 & 77.32 & $6.4 \pm 2.0$ \\
\hline MH13/00 A & 350 & 25 & 19 & 797 & 17.5 & 733.4 & 999 & 4000 & 98.05 & $4.2 \pm 2.0$ \\
\hline MH13/00 Z & 350 & 16 & 316 & 823 & 1490.8 & 3882.6 & 396 & 2679 & 38.99 & $8.7 \pm 2.2$ \\
\hline $\mathrm{MH} 14 / 00 \mathrm{~A}$ & 350 & 11 & 16 & 515 & 19 & 611.1 & 843 & 4000 & 98.28 & $4.6 \pm 2.4$ \\
\hline MH14/00 Z & 350 & 20 & 2136 & 4487 & 3985.5 & 8372.2 & 355 & 2679 & 4.65 & $9.6 \pm 2.2$ \\
\hline MH15/00 A & 520 & 25 & 6 & 450 & 5.4 & 401.6 & 947 & 4000 & 95.37 & $2.2 \pm 1.8$ \\
\hline MH15/00 Z & 520 & 6 & 110 & 393 & 2125.2 & 7592.6 & 396 & 2679 & 45.58 & $6.4 \pm 2.0$ \\
\hline MH16/00 A & 420 & 13 & 29 & 1225 & 41.3 & 1746.3 & 1101 & 7700 & 99.17 & $4.6 \pm 1.8$ \\
\hline MH16/00 Z & 420 & 13 & 424 & 1401 & 1703.2 & 5627.8 & 313 & 2679 & 22.91 & $5.5 \pm 1.4$ \\
\hline MH17/00 A & 400 & 18 & 30 & 1163 & 29.8 & 1155 & 1151 & 7700 & 100.0 & $5.2 \pm 2.0$ \\
\hline MH17/00 Z & 400 & 14 & 440 & 1320 & 1656.7 & 4970.2 & 373 & 2679 & 97.59 & $7.1 \pm 1.8$ \\
\hline MH20/00 A & 300 & 15 & 32 & 1225 & 46 & 1761.7 & 1103 & 4000 & 99.74 & $5.0 \pm 1.8$ \\
\hline $\mathrm{MH} 21 / 00 \mathrm{~A}$ & 300 & 30 & 43 & 1667 & 27.9 & 1082.7 & 1156 & 4000 & 97.82 & $5.2 \pm 1.6$ \\
\hline MH21/00 Z & 300 & 7 & 268 & 533 & 2376.6 & 4726.7 & 302 & 2679 & 94.42 & $8.7 \pm 2.2$ \\
\hline $\mathrm{MH} 22 / 00 \mathrm{~A}$ & 350 & 16 & 74 & 2799 & 101.5 & 3838.8 & 1208 & 4000 & 100.0 & $5.6 \pm 1.4$ \\
\hline MH22/00 Z & 350 & 11 & 331 & 624 & 2174.8 & 4099.8 & 384 & 2679 & 25.29 & $11.3 \pm 3.0$ \\
\hline $\mathrm{MH} 23 / 00 \mathrm{~A}$ & 300 & 28 & 70 & 2787 & 42.7 & 1698.4 & 1312 & 4000 & 97.85 & $5.8 \pm 1.4$ \\
\hline MH23/00 Z & 300 & 20 & 1969 & 3190 & 4044.8 & 6553 & 337 & 2679 & 47.0 & $12.0 \pm 2.6$ \\
\hline $\mathrm{MH} 24 / 00 \mathrm{~A}$ & 300 & 18 & 47 & 1947 & 49.8 & 2062.4 & 1364 & 4000 & 99.70 & $5.7 \pm 1.8$ \\
\hline MH24/00 Z & 300 & 20 & 1031 & 3027 & 2776.9 & 8152.9 & 361 & 2679 & 4.42 & $7.1 \pm 1.6$ \\
\hline $\mathrm{MH} 25 / 00 \mathrm{~A}$ & 400 & 15 & 41 & 1914 & 59.4 & 2770.9 & 1416 & 4000 & 99.01 & $5.3 \pm 1.6$ \\
\hline MH25/00 Z & 400 & 14 & 595 & 1586 & 2165 & 5770.9 & 380 & 2679 & 16.27 & $8.0 \pm 2.0$ \\
\hline MH26/00 A & 300 & 16 & 39 & 2000 & 58.1 & 2981.5 & 1468 & 4000 & 97.92 & $5.0 \pm 1.6$ \\
\hline MH26/00 Z & 300 & 10 & 350 & 870 & 2840 & 7059.4 & 331 & 2679 & 90.41 & $7.7 \pm 1.8$ \\
\hline $\mathrm{MH} 27 / 00 \mathrm{~A}$ & 400 & 38 & 30 & 1813 & 11.1 & 668.4 & 1520 & 4000 & 99.97 & $4.4 \pm 1.6$ \\
\hline MH27/00 Z & 400 & 10 & 331 & 835 & 1950.8 & 4921.2 & 367 & 2679 & 87.42 & $8.4 \pm 2.0$ \\
\hline
\end{tabular}

$\mathrm{N}=$ Abundance of dated crystals, $\mathrm{N}_{\mathrm{i}}=$ Abundance of induced fission tracks, $\mathrm{r}_{\mathrm{s}}=$ Density of spontaneous fission tracks in the sample, $\mathrm{r}_{\mathrm{i}}=$ Density of induced fission tracks in the detector, $\mathrm{r}_{\mathrm{d}}=$ Density of fission tracks in the dosimeter, $\mathrm{N}_{\mathrm{d}}=$ Abundance of induced fission tracks in the dosimeter, $\mathrm{P}\left(\mathrm{c}^{2}\right)=\mathrm{c}^{2}$-value in $\%$

conditions are attained during decompression and are coeval with D3 deformation, which suggests that D3 deformation at deeper structural parts is active within the 37-26 Ma time span. A lower age limit of around $26 \mathrm{Ma}$ for this period correlates well with the termination of dextral respectively top-WSWand high-temperature- shearing of the Simplon ductile shear zone (Steck 1990), being constrained by U-Pb dating of the age of post-D3 granitic dike injections into the Isorno-Orselina zone and Monte Rosa nappe (Schärer et al. 1996; Romer et al. 1996; see also Steck \& Hunziker 1994) between 29 Ma and 26 Ma ago.

Hence, the correlation of the Simplon ductile shear zone (D2 of Steck \& Hunziker 1994) with our third deformation phase, i.e. the first backfolding phase and associated dextral shearing, is supported by these timing constraints. From published and own petrological data it is obvious that temperatures prevailing during D3 deformation increase towards the east, i.e. towards deeper structural levels. In addition, the radiometric data indicate that D3 deformation is heterochroneous and becomes increasingly younger towards the east and towards deeper structural levels. Consequently, the first stages of exhumation (D3) related to the new kinematic regime of back-folding and/or -shearing during D3/D4, associated with dextral shearing and/or orogen-parallel stretch of the D1/D2 nappe stack in the working area, is of progressively younger age towards deeper structural levels in the east.

\section{Second phase of backfolding and normal faulting along the Simplon line (D4)}

D4 -folding occurred at lower temperatures $\left(<\mathrm{c} .570^{\circ} \mathrm{C}\right)$ and is related to dextral shearing, particularly in the southern limb of the Vanzone antiform. It is also contemporaneous with normal faulting along the Simplon line (see below).

Gold bearing veins, the ages of which range between around $32 \mathrm{Ma}$ (Brusson) and $25 \mathrm{Ma}$ (Ossola), tend to become younger towards the deeper structural units in the east (Dal Piaz et al. 1973; Diamond \& Wiedenbeck 1986; Pettke et al. 1999). These veins are found all along the trace of the axial plane of the major Vanzone antiform, suggesting a genetic link with D4-deformation. The area around the southwestern top of the Monte Rosa nappe in the Zermatt area is characterized by a marked gradient in apatite fission track cooling ages. While ages between 10-14 Ma are typical for the northern 


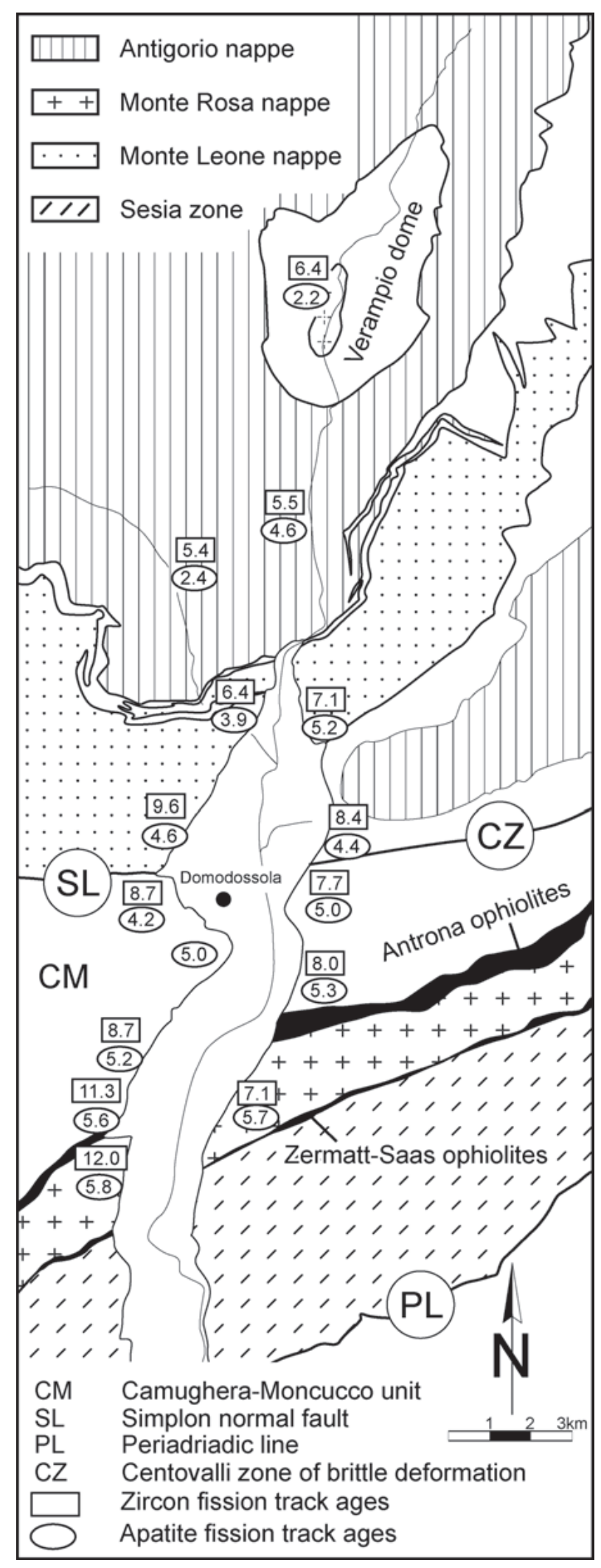

Fig. 15. Tectonic map of the upper part of the Ossola valley, showing zircon (rectangle) and apatite (oval) fission track ages in Ma (see Hess, 2003, deposited at the library of the Geological Institute Basel for more details). parts of the western Monte Rosa nappe, ages between 25-27 Ma are found in the southern parts (Hurford et al. 1989, his Fig. 8). This suggests differential exhumation of the northern limb of the Vanzone antiform relative to its southern limb somewhere within the 27 to $10 \mathrm{Ma}$ time interval. The structural data concerning D4 deformation presented earlier suggest a direct relationship between the formation of D4 backfolds (i.e. the Vanzone, Brevettola and Masera folds) in the south and normal faulting along the Simplon line on the other side. According to Mancktelow (1992) normal faulting along the Simplon line, associated to backfolding further to the north (Berisal- and Glishorn- folds), was active between $19 \mathrm{Ma}$ and $11 \mathrm{Ma}$ ago. This confirms the postulate that backfolding and orogen-parallel normal faulting are contemporaneous. In summary, all these data suggest that D4, (i.e. second backfolding phase and associated dextral shearing) started to be active in late Oligocene times (at about $27 \mathrm{Ma}$ ago), and was still active during the Miocene (19-10 Ma) when normal faulting occurred along the Simplon line.

Normal faulting in the Simplon domain is marked by jumps in zircon and apatite fission track ages and by a significant jump in metamorphic grade from greenschist facies conditions in the hangingwall to amphibolite facies conditions in the footwall (Wagner et al. 1977; Soom 1990; Mancktelow 1992; Grasemann \& Mancktelow 1993; Steck \& Hunziker 1994; Oberhänsli et al. 2004). Our own data from the Ossola valley, however, yielded no jump in zircon- and apatite- fission track ages across the suspected eastern continuation of the Simplon line, central ages ranging between 6.4-12 $\mathrm{Ma}$ and 2.2-5.8 Ma, respectively (Fig. 15, Tab. 1; Hess 2003). Note that these ages become continuously and progressively older going from north to south. This indicates late regional uplift of the more northern parts of the area around the Toce culmination. As there is no discrete jump in zircon- and apatite-fission track ages that would mark the eastern continuation of the Simplon line in the area of the Ossola valley, the discrete Simplon normal fault cannot have an eastward continuation in terms of differential exhumation by tectonic unroofing. Hence, it terminates somewhere along the lower Bognanco valley, contrary to the findings of Mancktelow (1990) and Steck (1999), who suggest a continuation of the Simplon line across the Ossola valley and into the Isorno valley.

Temperatures during mylonitisation along the Simplon normal fault and its hypothetical continuation into the Isorno valley increase from the northwest to the southeast and east, but did not exceed $550^{\circ} \mathrm{C}$ (Mancktelow 1990). These increasing temperatures, if reflecting exhumation of progressively deeper units in the footwall, would suggest that the differential displacement across this normal fault should increase towards the east, differentially exhuming progressively more deeply buried, i.e. higher metamorphic rocks north of this supposed eastern continuation of the Simplon normal fault against lower grade mylonites expected further south. Contrary the main foliation is of a high metamorphic grade (sillimanite grade at around $650^{\circ} \mathrm{C}$ ) south of the eastern continuation of the Sim- 
plon normal fault across the Ossola valley i.e. in the suspected hanging wall of the normal fault. Hence, the lack of a significant metamorphic "jump" across the supposed eastern continuation of the Simplon normal fault in the Ossola valley also contradicts the postulate of an eastward continuation of the Simplon line.

Finally, a broad mylonitic belt in the sense of an eastward continuation of the Simplon normal fault is not observed either. Instead, older pre-D4 stretching lineations, steeply plunging to the E to ESE, are observed in the Bognanco valley, indicating that late stage syn-D4 deformation is not pervasive in the Bognanco valley (Fig. 10, Steck \& Hunziker 1994, their Fig. 3).

We conclude that there is ample evidence that the Simplon normal fault has no eastward continuation and terminates somewhere along lower Bognanco valley. However, the associated displacements and strains associated with D4 Simplon normal faulting must be partitioned into other contemporaneous structures along Bognanco valley. The abrupt change into an E-W-strike of the mylonites related to the Simplon normal fault near Bagni di Bognanco and the eastern termination of this normal fault suggests transformation into dextral shearing further to the south and east, the Simplon normal fault representing a tensile bridge, that links dextral shearing in the working area to that observed further to the NW along the Rhone valley (Steck 1984, 1987). Note however that such late stage dextral shearing is not localized within our study area, dextral shearing being diffuse and associated with D4-folding of the Masera and Brevettola folds, well documented in case of the southern limbs of the Vanzone- and the Brevettola- antiforms (Figs. 8, 10,11). This second phase of backfolding and associated dextral shearing must have terminated before about $12 \mathrm{Ma}$ ago, when the southern part of the working area situated along the Ossola valley cooled below the zircon fission track temperature, no longer allowing for ductile folding. Since brittle deformation along the Centovalli line in Vigezzo valley was shown to clearly overprint D4 folds, the Centovalli line must have been active after the end of D4 deformation, i.e. after $12 \mathrm{Ma}$ ago. Therefore it cannot represent the eastern continuation of the Simplon normal fault either.

\section{Discussion}

\section{Metamorphic history of the working area}

The P-T estimates presented and cited in this study suggest that the $\mathrm{CM}$ unit, including the deeper and more eastern parts of the Monte Rosa nappe, underwent high-pressure metamorphism characterized by relative high temperatures (c. 620 $700^{\circ} \mathrm{C}$ at $12.5-16 \mathrm{kbar}$ ) or high T/P ratios (Keller et al. 2004; Keller et al. 2005a) when compared to high-pressure metamorphism in the Western Alps. High T/P ratios, i.e high-T eclogites (Newton 1986) are also indicated for the high-pressure stage in the Antrona ophiolites (Colombi \& Pfeifer 1986) as well as for other structurally deep nappe systems, derived from

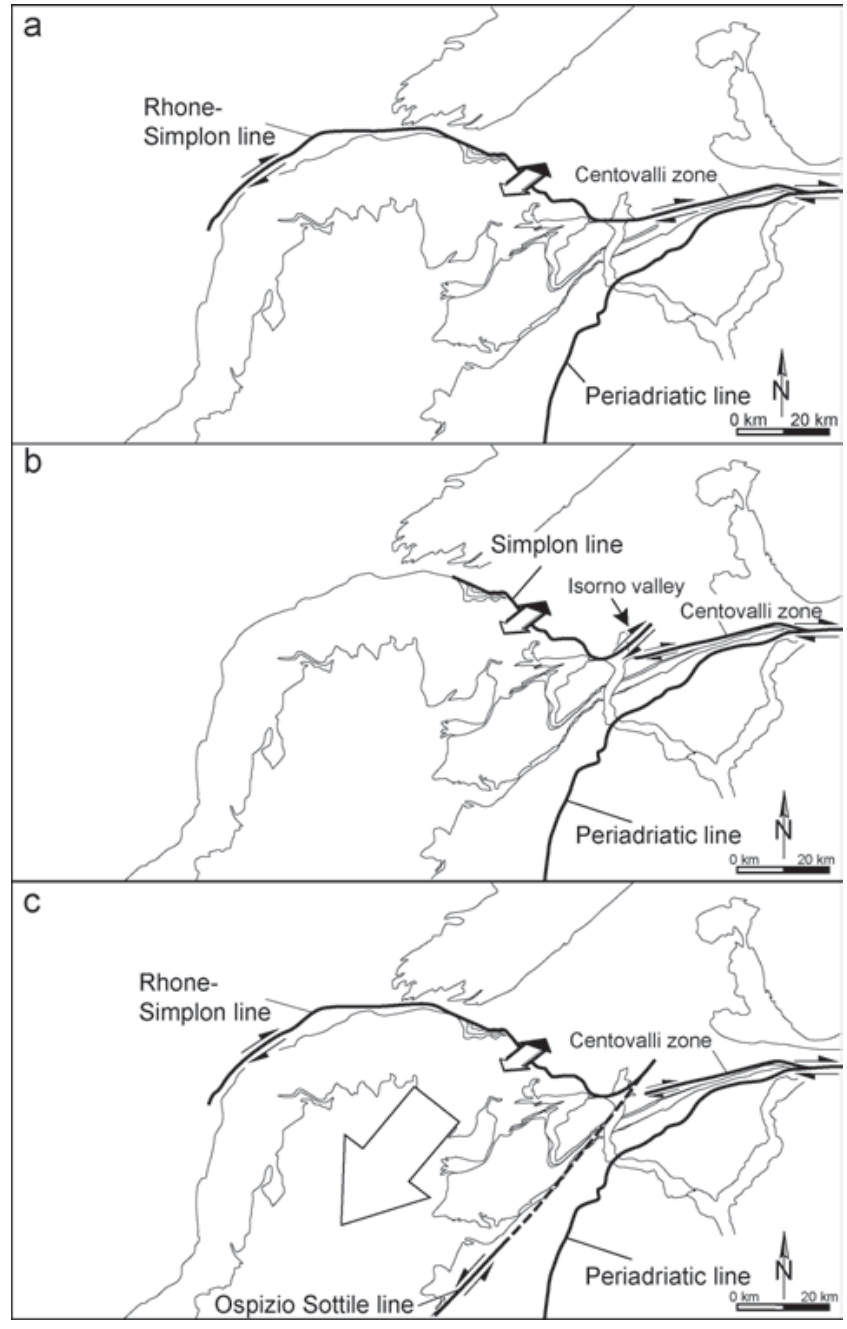

Fig. 16. Simplified tectonic map of the Penninic Alps after "Tektonische Karte der Schweiz" (Spicher, 1976) showing the various models and interpretations of late stage faulting in the vicinity of the Simplon line (see text for references).

a) Dextral shearing along the Rhone line is transferred via normal faulting and dextral shearing along the Simplon line respective Centovalli zone to the Periadriatic line.

b) Ductile deformation features of normal faulting along the Simplon line are transferred into dextral shearing in the Isorno valley.

c) Fault bounded extrusion of the hanging block of the Simplon normal fault or the Pennine-Graian Alps block of Bistacchi \& Massironi (2000).

the European margin and/or the Valaisan ocean according to Schmid et al. (2004) such as the Gorduno-Mergoscia zone and southern Adula and Cima Lunga (Spalla et al. 1996). In contrast lower $\mathrm{T} / \mathrm{P}$ ratios are obtained for the structurally higher units in the west (Zermatt-Saas Fee ophiolites), including the western part of the Monte Rosa (Spalla et al. 1996). Hence, it appears that the CM unit, Antrona ophiolites and the eastern parts of the Monte Rosa nappe are part of the high-T eclogitic belt positioned at relatively deeper structural levels.

In most structurally higher units in the west, characterized by lower T/P ratios decompression is far from isothermal, 


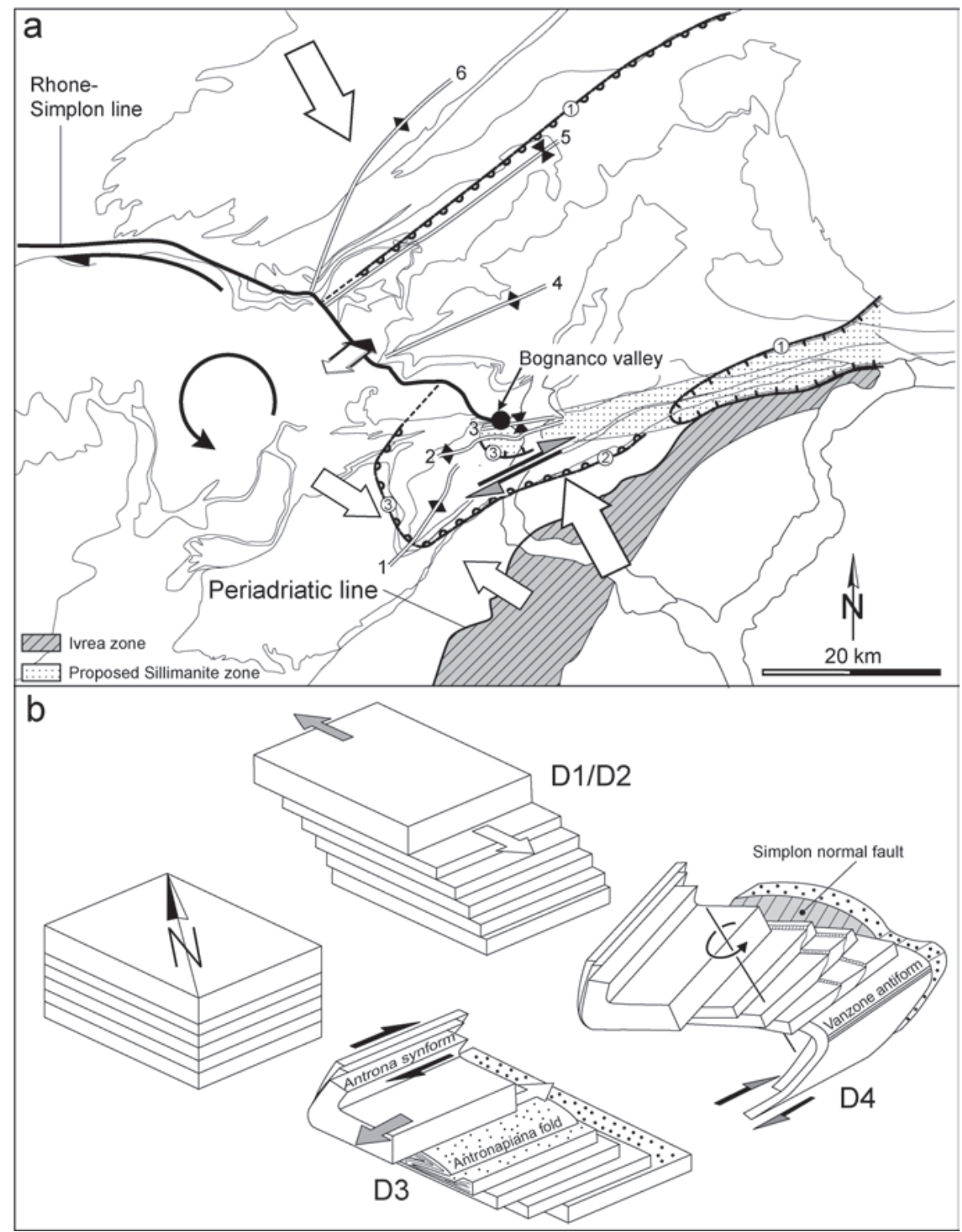

Fig. 17.

a) Interpretative tectonic map serving for the discussion of the kinematics during D4 deformation (see text, and Fig. 1 for tectonic units and mineral zone boundaries). Note that the displacement associated with normal faulting along the Simplon line decreases towards the southeast as the upper block of the Simplon line rotates around a pole indicated by the black dot. Dextral shearing occurs particularly in the southern limb of the Vanzone- and Brevettola- backfolds and modifies the metamorphic zonation that pre-dates D4 deformation. (Folds: 1=Vanzone antiform, $2=$ Brevettola antiform, $3=$ Masera synform, $4=$ Toce antiform, 5=Berisal synform, $6=$ Glishorn antiform)

b) A card-sliding model to illustrate the kinematic history established in the study area. The original is sheared first by top-NW movements during D1/D2 deformation and associated nappe stacking. During D3 it is sheared towards the west and the first backfolds are formed. At lower structural levels this shearing occurs in a flat lying- or SE dipping- nappe pile. Note that top-west shearing appears dextral in the overturned limb of D3 backfolds. During D4 deformation the second generation of backfolds are formed and the Simplon fault rotates the hanging wall with respect to its footwall.

while the eastern areas are characterized by relatively high $\mathrm{T} / \mathrm{P}$ ratios during the high-pressure stage, exhibit near-isothermal decompression (Nagel et al. 2002; Meyre et al. 1997, 1999; Keller 2004) or even heating during decompression (Engi et al. 2001b and refs. therein). This results in a metamorphic stage often referred to as "Barrow-type" or "Lepontine". In the following discussion we assume near-isothermal decompression since in our working area (Keller et al. 2005a), as well as in the southern Adula nappe (Nagel et al. 2002), the minerals indicative for Barrow-type metamorphism (e.g. staurolite) definitely grow at the expense of high-pressure mineral parageneses.

It is interesting to note that the eastern areas characterized by high T/P ratios, except for the Antrona ophiolites, predominately consist of crystalline continental crust, which has a sig- nificant potential for radiogenic heat production (Rybach \& Buntherbarth 1982). Recent numeric modelling predicts that the presence of such material either within an accretionary wedge or as accreted continental material within the subduction channel is crucial for explaining "Barrov-type" $\mathrm{P}-\mathrm{T}$ conditions, either during near-isothermal decompression, or during a syn-decompression heating pulse (Jamieson et al. 1998; Engi et al. 2001b; Goffé et al. 2003). In the case of isothermal decompression, assumed to have prevailed in the study area, and assuming similar subduction rates and maximum depth of burial, this modelling suggests that the differences in the $\mathrm{T} / \mathrm{P}$ ratios between west and east most probably reflect differences in rock properties within the subduction channel. Since there is no evidence so far for a precursory HP/LT metamorphic stage 
in the units characterized by high $\mathrm{T} / \mathrm{P}$ ratios, we speculate that the higher $\mathrm{T} / \mathrm{P}$ ratios in the east indicate the presence of higher percentages of radiogenic crustal material within the subduction channel, the temperature differences between west and east being already established during peak-pressure conditions. Orogen-scale transects through the Alps (Schmid et al. 2004) indeed depict relatively higher amounts of subducted continental upper crust derived from the distal European margin (such as, for example, the Adula nappe) in the Central Alps (NFP-20 East profile), as compared to the Western Alps (ECORS-CROP profile), the area of the Monte Rosa nappe occupying an intermediate position (NFP 20 West).

In conclusion, we propose that the temperature gradient observed amongst the high-pressure units of the Western Alps and the southern parts of the Lepontine dome, respectively, are essentially inherited from the high-pressure stage, rather than being the result of a separate heating pulse that overprinted the high-pressure assemblages during a later metamorphic stage, i.e. the so-called "Lepontine event".

\section{The eastwards continuation of the Simplon normal fault}

Our deduction that the Simplon normal fault has no eastward continuation deserves some discussion, because the Simplon fault zone is often regarded as a transfer zone ("pull-apart") where dextral strike-slip movements along the Rhone line are transferred to the Periadriatic line in a overall dextral transpressive regime (e.g. Steck 1984, 1987; Schmid \& Kissling 2000; Fig. 16a). Other workers suggest that ductile deformation features associated to the Simplon normal fault continue towards the northeast into the Isorno valley (e.g. Mancktelow 1990; Fig. 16b). In this context it is interesting to note that the traces of the axial plane of major D4 backfolds show a systematic enechelon arrangement, accompanied by a change in their strike (Figs. 2, 4, 9, 17). In the west the axial plane trace of the Vanzone antiform strikes approximately NE-SW, while towards the east the axial plane traces of the Brevettola antiform and Masera synform tend to strike almost E-W. Note that this pronounced change in strike occurs south of where the Simplon normal fault swings into an E-W orientation near its termination in Bognanco valley (Fig. 17).

The spatial arrangement and the strike of the D4 axial plane traces suggest different directions and amounts of shortening affected the study area during D4 backfolding. While N$\mathrm{S}$ shortening prevailed in the eastern parts, the western parts underwent NW-SE shortening (Fig. 17). The change in orientation of these D4 axial plane traces roughly coincides with a point where the Adriatic Moho changes its topology, and where the Periadriatic line changes from an E-W strike to a NE-SW strike (Schmid \& Kissling 2000 their Fig. 5). Because of these remarkable relationships between deep- and shallowstructural features we suggest that the arrangement of the D4 axial plane traces is controlled by the topological change of the Adriatic Moho, i.e. by deep-seated structural features. It is proposed that the different directions of shortening and the eastern termination of the Simplon normal fault may both be due to Miocene dextral transpressive indentation of the a bowshaped complex topology of the Adriatic lower crust represented by the Ivrea zone and geophysical anomaly.

Indentation of a plastic Austroalpine/Penninic orogenic wedge by a rigid African promontory is often used in order to explain the arc of western Alps after collision (e.g. Tapponier 1977; Regenauer-Lieb 1996; Ceriani et al. 2001). Analogue experiments suggest that the indentation of India into Asia caused rotation and extrusion of Indochina with respect to the indentation of India (Tapponier et al. 1982). A similar scenario for the Western Alps would be in accordance with recent paleomagnetic data obtained by Collombet et al. (2002), who suggest a large counter-clockwise rotation of the western Alps relative to both Europe and Adria. Thus, we think that the rotation of indented crustal segments and different amount of shortening are also a viable processes for explaining why the Simplon normal fault lacks a southeastern continuation. The Simplon fault zone may also terminate because of a combined effect of transformation into dextral shearing and decreasing amount of extension towards the east. Based on all these considerations we suggest that the Neogene Simplon fault represents a transfer zone joining differently shortened areas located to the north of axial plane traces of the Vanzone and Brevettola antiforms (Fig. 17). A rotational component would cause displacement by normal faulting to be highest along the northwestern segment of the Simplon line, where it is transferred into dextral shearing along the Rhone line. Conversely, displacement by normal faulting drops towards the southeastern termination of the Simplon fault zone, in accordance with the presented structural observations, the regional metamorphic pattern and the fission track data. In the northwestern Alps, situated at higher structural levels and more to the west than the area discussed here the above scenario possibly appears in the form of a SW-directed lateral extrusion of the hanging block of the Simplon normal fault, i.e. the PennineGraian Alps block, bounded by the Ospizio Sottile, SimplonRhone and Chamonix faults (Fig. 16c). This kinematic picture is based on brittle deformation analysis and is found to be active from the Miocene onwards (Bistacchi \& Massironi 2000). These authors, however, propose the connection of their Ospizio Sottile fault with the eastern continuation of the Simplon normal fault (Fig. 16c), which is not confirmed by this study and fully lacks any field evidence.

\section{Conclusions}

1) Composite D1/D2 deformation and related top-N or topNW thrusting started at high-pressure conditions (c. 12.5-16 kbar) and under relatively high temperatures (c. $\left.620-700^{\circ} \mathrm{C}\right)$. Published radiometric data for the Eocene high-pressure stage suggest that top-SE shearing at the structural top of the high-pressure units is coeval with top$\mathrm{N}$ or top-NW thrusting at the base. This kinematic situation 
suggests a differential ascent of high-pressure units relative to the surrounding units during nappe stacking and associated crustal shortening. Thus, exhumation related to D1/D2 deformation rather occurs by extrusion within the subduction channel than by crustal extension.

2) In the higher structural levels D3 backfolding and/or backthrusting start in late Eocene times under greenschist facies conditions. Towards deeper structural levels D3 deformation progressively becomes younger. This is due to the fact that higher temperatures prevailed longer in the east; hence the brittle-viscous transition in the area of the Ossola valley is younger than at higher structural levels in the west. Consequently, the main foliation in the Ossola valley is a composite foliation formed during the first three deformation phases (D1-D3) and is affected by high-temperature metamorphism. High temperatures at relatively moderate pressures at deeper structural levels are attained due to a component of extensional unroofing during D3 deformation that delays cooling during decompression and thus causes approximately isothermal decompression. D3 deformation ceased in late Oligocene times.

3) An open fold pair, consisting of Masera synform and Brevettola antiform, forms the eastern continuation of the major Vanzone antiform. This contradicts the proposition of Milnes et al. (1981) that the D4 Vanzone antiform becomes an isoclinal fold towards the east. Structural arguments, as well as published radiometric data, suggest that the major Vanzone and Brevettola antiforms formed at the same time as the Simplon normal fault. Two geometrical features of D4 deformation change overall style in the Bognanco valley, situated exactly south of the swing in orientation of the Simplon normal fault. Firstly, the Masera synform nucleates and amplifies towards the east into a major D4 fold. Secondly, the D4 fold axes change in strike from SW-NE to W-E.

4) As the Simplon normal fault dies out towards the east, the Masera synform nucleates and amplifies towards the same direction. As hypothesised by Milnes et al. (1981) displacement along the Simplon normal fault (Mancktelow 1990) is additionally transformed into the southern limb of Vanzone and Brevettola antiforms, where D4 folding is also associated with dextral shearing.

5) It is strongly suggested that paleogeographic reconstructions based on the undoing of all the major fold structures observed in the nappe pile of the Simplon-Pennine Alps and projected onto a single N-S orientated profile plane may lead to ambiguous results. This suggestion is supported by the fact that the two backfolding phases are associated with top-WSW and dextral shearing, and pervasive deformation becomes progressively younger towards the east, i.e. towards deeper structural parts. Hence, there are large out of profile movements during D3 and D4 deformation that potentially produce suspicious results, if paleogeographic reconstructions are obtained by retro-deformation in profile view only.
6) The Antrona unit in Bognanco valley, which is structurally positioned in the northern limb of the D4 Masera synform, dipping towards the SE, strikes all the way to the mouth of the Bognanco valley. Across the Ossola valley numerous aligned lenses of ophiolitic rocks (amphibolites, serpentinites and metagabbros) in a position identical to that of the Antrona unit in the Bognanco valley, can be found in the southern slope of the Isorno valley (see also Wieland 1966). There staurolite-bearing garnet-mica schists have also frequently been observed (see also Bearth, 1956b). Such staurolite-bearing garnet-mica schists are typical rocks for the western parts of CM unit, situated west of the Ossola valley. Thus, it is concluded that the rocks of Antrona unit and the northern rim of the CM unit find their eastern continuation in the southern slope of the Isorno valley and not in the Vigezzo valley, as proposed by most tectonic maps (e.g. Steck et al. 1999, 2001). Following Bearth (1956b), we suggest that at least parts of the "Pioda di Crana zone" represent the eastern equivalents of the $\mathrm{CM}$ unit west of the Ossola valley.

\section{Acknowledgments}

This work has benefited from comments and discussions with A. Berger. Furthermore we acknowledge the contributions of the members of the Basel "Western Alps group" and "Monte Rosa group" (R. Bousquet, S. Bucher, S. Ceriani, J. Kramer and N. Froitzheim) which were instrumental for our own thinking. In addition we had support from R. Abart, C. De Capitani, H. Stünitz and K. Waite. The constructive reviews by G. V. Dal Piaz and M. Ballèvre helped to substantially improve the manuscript. This study was supported by the Swiss National Foundation Grants Nr. 20-61814.00 and 2000068020.02/1.

\section{Appendix}

\section{Thermodynamic calculations}

Equilibrium phase diagrams were calculated for specified bulk rock compositions in the system KNCFMASH. Calculations were made with the DOMINO software (De Capitani \& Brown 1987; De Capitani 1994). Most thermodynamic data were taken from Berman (1988, update 92); staurolite and chloritoid data are from of Nagel et al. (2002), while garnet uses the solution model of Berman (1990). For the biotite binary (Phl, Ann) ideal mixing on three mixing sites, and for chlorite the solution model of Hunziker (2003). For feldspar we used the solution model of Fuhrman \& Lindsley (1988), for staurolite the solution model of Nagel et al. (2002). For muscovite/paragonite the solution model of Keller et al. (2005b), and for chloritoid the binary ideal mixing on one mixing site were used.

\section{REFERENCES}

Amstutz, A. 1954: Pennides dans l'Ossola et problèmes des raciness. Arch. Sci., Genève 7/6, 463-473.

Argand, E. 1911: Les nappes de recouvrement des Alpes Pennines et leurs prolongements structuraux. Beitr. Geol. Karte Schweiz, N.F. 31, 26pp.

Ballèvre, M. \& Merle, O. 1993: The Combin fault: compressional reactivation of the late Cretaceous-early Tertiary detachment fault in the Western Alps. Schweiz. Mineral. Petrogr. Mitt. 73, 205-227. 
Barnicoat, A. C., Rex, D.C., Guise, P. G. \& ClifF, R. A. 1995: The timing of and nature of greenschist facies deformation and metamorphism in the upper Pennine Alps. Tectonics 14, 279-293.

BEARTH, P. 1939: Über den Zusammenhang von Monte Rosa- und BernhardDecke. Eclogae geol. Helv. 32, 101-111.

Bearth, P. 1953: Blatt Zermatt, Geologischer Atlas der Schweiz. Nr. 29. Schweiz. Geol. Kommission, Basel.

Bearth, P. 1954a: Blatt Monte Moro, Geologischer Atlas der Schweiz. Nr. 30. Schweiz. Geol. Kommission, Basel.

Bearth, P. 1954b: Blatt Saas, Geologischer Atlas der Schweiz. Nr. 31. Schweiz. Geol. Kommission, Basel.

BeARTH, P. 1956a: Geologische Beobachtungen im Grenzgebiet der lepontinischen und penninischen Alpen Eclogae. geol. Helv. 49/2, 279-290.

BEARTH, P. 1956b: Zur Geologie der Wurzelzone östlich des Ossolatales. Eclogae geol. Helv. 49, 267-278.

Bearth, P. 1957a: Die Umbiegung von Vanzone (Valle Anazasca). Eclogae geol. Helv. 50, 161-170.

BEARTH, P. 1957b: Erläuterungen Blatt Saas und Monte Moro, Geologischer Atlas der Schweiz. Nr. 30, 31. Schweiz. Geol. Kommission, Basel.

Bearth, P. 1958. Ueber den Wechsel der Mineralfazies in der Wurzelzone des Penninikums. Schweiz. Mineral. Petrogr. Mitt. 38, 363-373.

Berman, R. G. 1988. Internally-consistent Thermodynamic Data for Minerals in the System $\mathrm{Na}_{2} \mathrm{O}-\mathrm{K}_{2} \mathrm{O}-\mathrm{CaO}-\mathrm{FeO}-\mathrm{Fe}_{2} \mathrm{O}-\mathrm{Al}_{2} \mathrm{O}_{3}-\mathrm{SiO}_{2}-\mathrm{H}_{2} \mathrm{O}-\mathrm{CO}_{2}$. J. Petrology, 29, 445-552.

Berman, R. G. 1990. Mixing properties of Ca-Mg-Fe-Mn garnets. Amer. Mineralogist 75, 328-344.

Bigioggero, B., Boriani, A., Colombo, A. \& Tunesi, A. 1981: Età e caratteri petrichimici degli ortogneiss della zona Moncucco-Orselina nell' area Ossolana. Rend. Soc. It. Min. Petr. 38, 207-218.

Bistacchi, A., Dal Piaz, G. V., Massironi, M., Zattini, M. \& Balestrieri, M. L. 2001: The Aosta-Ranzola extensional fault system and Oligocenepresent evolution of the Austroalpine-Penninic wedge in the northwestern Alps. Int. J. Earth Sci. 90, 654-667.

Bistacchi, A. \& Massironi, M. 2000: Post-nappe brittle tectonics and kinematic evolution of the north-western Alps: an integrated approach. Tectonophysics 327, 267-292.

Blumenthal, M. M. 1952: Beobachtungen über den Bau und Verlauf der Muldenzone von Antrona. Eclogae geol. Helv. 45/2, 220-251.

Borghi, A., Compagnoni, R. \& SAndrone, R. 1996: Composite P-T paths in the internal Penninic massifs of the western Alps: Petrological constrains to their thermo-mechanical evolution. Eclogae geol. Helv. 89, 345-367.

Bowtell, S. A., ClifF, R. A. \& Barnicont, A. C. 1994: Sm-Nd isotopic evidence on the age of elogitization in the Zermatt-Saas ophiolite. J. metam. Geology 12,187-196.

BUCHER, S. 2003: The Brainconnais units along the ECORS-CROP transect (Italien-French Alps): structures, metamorphism and geochronology. PhD Univ. Basel, 201pp.

Bucher, S.,Ulardic C., Bousquet R., Ceriani S., Fügenschuh B., GoufFON Y. \& SCHMID S. M 2004: Tectonic evolution of the Briançonnais units along a transect (ECORS-CROP) through the Italian-French Western Alps, Eclogae geol. Helv. 97, 321-345.

CArtwright, J. \& Barnicoat, A. C. 2002: Petrology, geochronology, and tectonics of shear zones in the Zermatt-Saas and Combin zones of the Western Alps. J. Metamorphic Geology 20, 263-281.

CARrupt, E. \& Schlup, M. 1998: Métamorphism et tectonique du versant sud du Val Bognanco Pennique, (Alpes italiennes). Bull. Soc. Vaud. Sci. Nat. $86,29-59$.

Ceriani, S., Fügenschun, B. \& Schmid, S. M. 2001: Multi-stage thrusting at the "Penninic Front" in the Western Alps between Mont Blanc and Pelvoux massif. Int. J. Earth Sci. 90, 685-702.

Chemenda, A., Matte, P. \& Sokolov, V. 1997: A model of Paleozoic obduction and exhumation of high-pressure/low-temperature rocks in the southern Urals. Tectonophysics 276, 217-227.

Chopin, C. \& Monié, P. 1984: A unique magnesiochloritoid-bearing, highpressure assemblage from the Monte Rosa, Western Alps: petrologic and ${ }^{40} \mathrm{Ar}-{ }^{39} \mathrm{Ar}$ radiometric study. Contr. Mineral. Petrol. 87, 388-398.
Collombet, M., Thomas, J. C., Chauvin, A., Tricart, P., Bouillin, J. P., Gratier, J. P. 2002: Counterclockwise rotation of the western Alps since the Oligocene: New insights from paleomagnetic data. Tectonics 21/4, $1-15$.

Colombi, A. \& Pfeifer, H-R. 1986. Ferrogabbroic and basaltic meta-eclogites from the Antrona mafic-ultramafic complex and Centovalli-Locarno region (Italy and Southern Switzerland)-first results. Schweiz. Mineral. Petrogr. Mitt. 66, 99-110.

Colombi, A. 1989: Métamorphisme et géochimie des roches mafiques des Alpes ouest-centrales (géoprofil Viège- Domodossola- Locarno). Mémoires de Géologie 4, Imprivite S. A. Lausanne Genève, 216pp.

Dal Piaz, G. V., Hunziker, J. C. \& Martinotti, G. 1972: La Zona SesiaLanzo e l'evoluzione tettonico-metamorfica delle Alpi nordoccidentali interne. Mem. Sci. Geol. It. 11, 433-466.

Dal Piaz, G. V., Hunziker, J. C. \& Martinotti, G. 1973: Excursion of the Sesia zone of the Schweiz. Mineralogische und Petrographische Gesellschaft, September $30^{\text {th }}$ to October $3^{\text {rd }}$. Schweiz. Mineral. Petrogr. Mitt. 53, 477-490.

Dal Piaz, G. V. \& Lombardo, B. 1986: Early Alpine eclogite metamorphism in the Penninic Monte Rosa - Gran Paradiso basement nappes of the northwestern Alps. Blueschists and Eclogites. Geol. Soc. Amer. mem. 164, 249-265.

Dal Piaz, G. V. 1999: The Austroalpine-Peidmont nappe stack and the puzzle of the Alpine Tethys. Mem. Sci. Geol. 51, 155-176.

Dal Piaz, G. V. 2001: Geology of the Monte Rosa massif: historical review and personal comments. Schweiz. Mineral. Petrogr. Mitt. 81, 275-303.

De CAPITANI, C. \& Brown, T. H. 1987: The computation of chemical equilibrium in complex systems containing non-ideal solutions. Geochim. Cosmochim. Acta 51, 2639-2652.

De CaPitani, C. 1994: Gleichgewichts-Phasendiagramme: Theorie und Software. Berichte der Deutschen Mineralogischen Gesellschaft, Beihefte zum Europe. J. Mineralogy 6, 48.

Diamond, L. W. \& WiedenBeCK, M. 1986: K-Ar radiometric ages of the goldquartz veins at Brusson, Val d'Ayas, NW Italy: Evidence of midOligocene hydrothermal activity in the northwestern Alps. Schweiz. Mineral. Petrogr. Mitt. 66, 385-393.

ENGLAND, P. C. \& Thompson, A. B. 1984: Pressure-temperature-time paths of regional metamorphism I. Heat transfer during the evolution of regions of thickened continental crust. J. Petrology 25, 894-928.

Engi, M., Scherrer, N. C. \& Burri, T. 2001a: Metamorphic evolution of pelitic rocks of the Monte Rosa nappe: Constrains from petrology and single grain monazite age data. Schweiz. Mineral. Petrogr. Mitt. 81, 305-328.

Engi, M., Berger, A. \& Roselle, G. T. 2001b: Role of the tectonic accretion channel in collision orogeny. Geology 29, 1143-1146.

Escher, A., Hunziker, J. C., Marthaler, M., Masson, H., Sartori, M. and STECK, A. 1997: Geologic framework and structural evolution of the western Swiss-Italien Alps. In: Pfiffner, O. A., Lehner, P., Heitzmann, P., MÜller, St., Steck, A. (Eds.): Deep Structure of the Alps, Results of NRP 20. Birkhäuser. Basel Boston Berlin, 205-222.

Ferrara, G., Hirt, B., JäGER, E. \& NigGli, E. 1962: Rb-Sr and U-Pb age determination on the pegmatite of I Mondei (Penninic Camughera-Moncucco complex, Italien Alps and some Gneisses from the neighborhood). Eclogae geol. Helv. 55, 443-450.

Frey, M., Hunziker, J. C., Frank, W., Bocquet, J., Dal Piaz, G. V., JÄger, E. and Niggli, E. 1974: Alpine metamorphism of the Alps: a review. Schweiz. Mineral. Petrogr. Mitt. 54, 247-290.

Frey, M., Desmons, J. \& Neubauer, F. (Eds.) 1999: Metamorphic maps of the Alps. Published by the editors and as enclosure to Schweiz. Mineral. Petrogr. Mitt. 79.

Froitzheim, N., SChmid, S. M. \& Frey, M. 1996: Mesozoic paleogeography and the timing of eclogite facies metamorphism in the Alps: A working hypothesis. Eclogae geol. Helv. 89, 81-110.

Froitzheim, N. 2001: Origin of the Monte Rosa nappe in the Pennine Alps-A new working hypothesis. Geol. Soc. Am. Bull. 113, 604-614.

Fuhrman, M. L. \& Lindsley, D. H. 1988: Ternary-feldspar modelling and thermometry. Amer. Mineralogist, 73, 201-215. 
GebaueR, D. 1999: Alpine geochronology of the Central and Western Alps: new constraints for a complex geodynamic evolution. Eclogae geol. Helv. 79, 191-208.

Goffé, B., Bousquet, R., Henry, P. \& Le Pichon, X. 2003: Effect of the chemical composition of the crust on the metamorphic evolution of orogenic wedges. J. metam. Geology 21, 123-141.

Gosso, G., Dal Piaz, G. V., Piovano, V. \& Polino, R. 1979: High pressure emplacement of early-Alpine deformations and structural levels. Mem. Sci. Geol. 32, 15pp.

Grasemann, B. \& ManckTelow, N. S. 1993: Two-dimensional thermal modelling of normal faulting: The Simplon fault zone, central Alps, Switzerland. Tectonophysics 225, 155-165.

Grasemann, B. \& STÜWE, K. 2001: The development of flanking folds during simple shear and their use as kinematic indicators. J. Struct. Geol. 23, $715-424$.

Hess, M. 2003: Strukturgeologie und Spaltspurdatierungen an Apatit und Zirkon an der Simplonlinie im Gebiet um Domodossola (I). Unpublished diploma thesis, Univ. Basel.

Hunziker, J. C., Desmons, J. \& Hurford, A. J. 1992: Thirty-two years of geochronological work in the Central and Western Alps: a review on seven maps. Mémoires de Géologie 13, Imprivite S. A., Lausanne Genève, 59pp.

HunZIKER, J. C. 1969: Rb-Sr Altersbestimmungen aus den Walliser-Alpen Hellglimmer und Gesamtgesteinswerte. Eclogae geol. Helv. 62, 527-542.

HunziKeR, J. C. \& BeARTH, P. 1969: Rb-Sr Altersbestimmungen aus den Walliser-Alpen: Biotitalterswerte und ihre Bedeutung für die Abkühlungsgeschichte der alpinen metamorphose. Eclogae. geol. Helv. 62, 205-222.

HUNZIKER, P. 2003: The stability of tri-octahedral $\mathrm{Fe}^{2+}-\mathrm{Mg}-\mathrm{Al}$ chlorite. A combined experimental and theoretical study. Ph. D. Univ. Basel, 162pp.

HuRford, A. J., FlisCh, M. \& JäGER, E. 1989: Unravelling the thermo-tectonic evolution of the Alps: a contribution from fission track analysis and mica dating. In: Coward, D., Dietrich, D., Park, R. F. (Eds.): Alpine tectonics. Geol. Soc. Spec. Publ. 369-398.

JABOYEDOfF, M., BÉGLÉ, P. \& Lobrinus, S. 1996: Stratigraphic et évolution structurale de la zone de Furgg, au Front de la nappe du Monte Rosa. Bull. Soc. Vaud. Sci. Nat. 84/2,191-210.

Jamieson, R. A., Beaumont, C., Fullsack, F. \& Lee, B. 1998: Barrovian regional metamorphism: where's the heat? In: TREOLAR, P. J. \& O'BRIEN, P. J. (Eds.): What drives metamorphism and metamorphic reactions? Geol. Soc. Spec. Publ. 138, 23-51.

KelLer, L. M. \& SCHMID, S. M. 2001: On the kinematics of shearing near the top of the Monte Rosa nappe and the nature of the Furgg zone in Val Loranco (Antrona Valley, N. Italy): tectonometamorphic and paleogeographic consequences. Schweiz. Mineral. Petrogr. Mitt. 81, 347-367.

Keller, L. M., Abart, R., Stünitz, H. \& De Capitani, C. 2004: Deformation, mass transfer and mineral reactions in an eclogite facies shear zone in a polymetamorphic metapelite (Monte Rosa nappe, Western Alps). J. metam. Geology 22, 97-118.

Keller, L. M., Abart, R., Schmid, S. M. \& De Capitani C. 2005a: Phase relations and chemical composition of phengite and paragonite in pelitic schists during decompression: a case study from the Monte Rosa Nappe and Camughera-Moncucco Unit, Western Alps. J. Petrology 46, in press.

Keller, L. M., De Capitani, C. \& ABart, R. 2005b: A quaternary solution model for white micas based on natural coexisting phengite-paragonite Pairs. J. Petrology 46, in press.

Kramer, J. 2002: Structural evolution of the Penninic units in the Monet Rosa region (Swiss and Italien Alps. PhD Univ. Basel, 154pp.

KLeIN, J. A 1978: Post-nappe folding southeast of the Mischabel Rückfalte (Pennine Alps) and some aspects of the associated metamorpism. Leidse Geol. Meded. 51, 233-312.

LACASSIN, R. 1987: Kinematics of the ductile shearing from outcrop to crustal scale in the Monte Rosa nappe, Western Alps. Tectonics 6, 69-88.

LAduron, D. 1976: L' antiforme de Vanzone. Etude pétrologique et structurale dans la valle Anazasca (Province de Novara, Italie). Mém. Inst. Géol. Univ. Louvain 28,1-121.

ManckTelow, N. S. 1990: The Simplon fault zone. Beitr. Geol. Karte Schweiz, NF 163.
ManckTElow, N. S. 1992: Neogene lateral extension during convergence in the Central Alps: Evidence from interrelated faulting and backfolding around the Simplonpass (Switzerland). Tectonophysics 215, 295-317.

Markley, M. J., Teyssier, C., Cosca, M. A., Caby, R., Hunziker, J. C. and SARTORI, M. (1998): Alpine deformation and 40Ar/39Ar geochronology of synkinematic white mica in the Siviez-Mischabel nappe, Western Pennine Alps, Switzerland. Tectonics 17, 407-425.

Merle, O, Cobbold, P. R. \& Schmid, S. M. 1989: Tertiary kinematics in the Lepontine dome. In: Coward, M. P., Dietrich, D. \& PARK, R. G. (Eds.): Alpine Tectonics. Geol. Soc. Spec. Publ. 45, 113-134.

MERLYN, M. 1977: Structure et métamorphisme du complex Camughera-Moncucco entre la ValleAnzasca et le Val Brevettola (Province de Novara, Italie). PhD Univ. catholique de Lovain.

Meyre, C., De Capitani, C. \& Partsch, J. H. 1997: A ternary solid solution model for omphacite and its application to geothermobarometry of eclogites form the middle Adula nappe (Central Alps, Switzerland). J. metam. Geol. 15, 687-700.

Meyre, C., De Capitani, C., Zack, T. \& Frey, M. 1999: Petrology of highpressure metapelites from the Adula nappe (Central Alps, Switzerland). J. Petrology 40, 199-213.

Milnes, A. G., Greller \& M., Müller, R. 1981: Sequenz and style of major post- nappe structures, Simplon- Pennine Alps. J. Struct. Geol. 3, 411-420.

MülLER, R. 1983: Die Struktur der Mischabelfalte (Penninische Alpen). Eclogae. geol. Helv. 79, 391-416.

Nagel, T., De Capitani, C. \& Frey, M. 2002: Isogrades and $P$ - $T$ evolution in the Southeastern Lepontine Dome (Graubünden, Switzerland). J. metam. Geol., 20, 309-324.

Newton, R. C. 1986: Metamorphic temperatures and pressures of group B and C eclogites. Geol. Soc. amer. mem. 164, 17-30.

NigGLI, E. 1970: Alpine Metamorphose und alpine Gebirgsbildung. Fortschr. Mineralogie 47, 16-26.

Novarese, A. \& Stella, A. 1913: Carta Geologica d'Italia (Domodossola). Istituto Geografico De Agostini.

Oberhänsli, R., Bousquet, R., Engi, M., GoffeÉ, B., Gosso, G., Handy, M., Höck, V., Koller, F., Lardeaux, J.-M., Poliano, R., Rossi, P., Schuster, R., Schwarz, S. \& Spalla, M. 2004: Metamorphic structure of the Alps (1:1'000'000), Commission for the Geological Map of the World (UNESCO), Paris.

Pettke, T., Diamond, L. W. \& Villa, I. M. 1999: Mesothermal gold veins and metamorphic devolatilization in the northwestern Alps: The thermal link. Geology 27, 641-644.

Pfeifer, H. R., Colombi, A. \& Ganguin, J. 1989: Zermatt-Saas and Antrona zone: A petrographic and geochemical comparison of polyphase metamorphic ophiolites of the West-Central Alps. Schweiz. Mineral. Petrogr. Mitt. 69, 217-236.

Ramsay, J. G. \& Huber, M.I. 1987: The Techniques of Modern Structural Geology, Vol.2. Academic Press, London 475-504.

Reddy, S. M., WheELER, J. \& ClifF, R. A. 1999: The geometry and timing of orogenic extension: an example from the Western Alps. J. metam. Geology $17,573-589$.

Regenauer-Lieb, K. 1996: Plactic velocity vector diagrams applied to indentation and transpression in the Alps. J. Geodynamics 21, 339-353.

Reinhardt, B. 1966: Geologie und Petrographie der Monte Rosa Zone, der Sesia Zone und des Canavese im Gebiet zwischen Valle d'Ossola und Valle Loana. Schweiz. Mineral. Petrogr. Mitt. 46, 553-678.

Romer, R. L., Schärer, U. \& SteCK, A. 1996: Alpine and pre-Alpine magmatism in the root-zone of the western Alps. Contrib. Mineral. Petrol. $123,138-158$

Rubatto, D., Gebauer, D. \& Compagnoni, R. 1997: Dating the UHP/HP metamorphism in the western Alps (Sesia-Lanzo and Zematt- Saas- Fee): Evidence for subductions events at theCretaceous- Tertiary boundary in the Middle Eocene. Fifth Internat. Eclogite Conf. Ascona supplement No1 to TERRA nova 9, 30-31.

Rybach, L. \& Buntebarth, G. 1982: Relationships between petrophysical properties density, seismic velocity, heat generation, and mineralogical constitution. Earth and planet. Sci. Lett. 57, 367-376. 
Schärer, U., CoscA, M., Steck, A. \& Hunziker, J. 1996: Termination of major ductile strike-slip shear and differential cooling along the Insubric line (Central Alps): U-Pb, Rb-Sr and ${ }^{40} \mathrm{Ar} /{ }^{39} \mathrm{Ar}$ ages of cross-cutting pegmatites. Earth and planet. Sci. Lett.141, 331-351.

Schmid, S. M. \& Kissling, E. 2000: The arc of the western Alps in the light of geophysical data on deep crustal structure. Tectonics 19, 62-85.

Schmid, S. M., Fügenschuh, B., Kissling, E. \& Schuster, R.: 2004: Tectonic map and overall architecture of the Alpine orogen. Eclogae geol. Helv. 97, 93-117.

Simpson, C. \& Schmid, S. M. 1983: An evaluation of criteria to deduce the sense of movement in sheared rocks. Geol. Soc. Am. Bull. 94, 1281-1288.

Soom, M. A. 1990: Abkühlungs- und Hebungsgeschichte der Externmassive und der penninischen Decken beidseits der Simplon-Rhone-Linie seit dem Oligozän: Spaltspurdatierungen an Apatit/Zirkon und K-Ar Datierungen and Biotit/Muskowit (westliche Zentralalpen). PhD Univ. Bern, 64pp.

Spalla, M. I., Lardeaux, J. M., Dal Piaz, G. V., Gosso, G. \& Messiga, B. 1996: Tectonic significance of Alpine eclogites. J. Geodynamics, 21, 257-285.

SpICHER, A. 1976: Tektonische Karte der Schweiz 1: 500,000. Schweiz. Geol. Kommission.

StauB. R. 1937: Gedanken zum Bau der Westalpen zwischen Bernina und Mittelmeer. Vierteljahrsschrift der Naturf. Gesellschaft in Zürich, Jahrg. $82,140 \mathrm{pp}$.

STECK, A. 1984: Structures de déformation tertiaires dans les Alpes centrales. Eclogae geol. Helv. 77, 55-100.

Steck, A. 1987: Le massif du Simplon-Réflexions sur la Cinématique des nappes de gneiss. Schweiz. Mineral. Petrogr. Mitt. 67, 27-45.

SteCK, A. 1990: Une carte des zones de cisaillement ductile dans les Alpes Centrales. Eclogae geol. Helv. 83, 603-626.

Steck, A. \& Hunziker, J. C. 1994: The Tertiary structural and thermal evolution of the Central Alps- Compressional and extensional structures in an orogenic belt. Tectonophysics 238, 229-254.
Steck, A., Bigioggero, B., Dal Piaz, G. V., Escher, A., Marchant, R., Martinotti, G. \& Payot, S. 1999: Carte tectonique des Alpes de Suisse occidental (1:100’000) Feuille 47 Monte Rosa. Landeshydrologie und -geologie, Bern.

Steck, A., Epard, J-L., Escher, A., Gouffon, Y. \& Masson, H. 2001: Carte tectonique des Alpes de Suisse occidentals. Notice explicative. Landeshydrologie und -geologie, Bern.

Stipp, M., Stünitz, H., Heilbronner, R. \& Schmid, S. M. 2002: The eastern Tonale fault zone: 'natural laboratory' for crystal plastic deformation in quartz over a temperature range from 250 to $700^{\circ}$ C. J. Struct. Geol. 24, 1861-1884.

TAPPONIER, P. 1977: Evolution tectonique du système alpin en Méditerranée: poinconnement et écrasement rigid-plastique. Bull. Soc. géol. France 19, 437-460.

Tapponier, P., Peltzer, G., Le Dain, A. Y., Armijo, R. \& Cobbold, P. 1982 Propagation extrusion tectonics in Asia: New insights from simple experiments with plasticine. Geology 10, 611-616.

Thompson, A. B. \& England, P. C. 1984: Pressure-temperature-time paths of regional metamorphism II. Their inference and interpretation using mineral assemblages in metamorphic rocks. J. Petrology 25, 929-955.

Wagner, G. A., Reimer, G. M. \& Jäger, E. 1977: Cooling ages derived by apatite fission-track mica Rb-Sr and K-Ag dating: The uplift and cooling history of the Central Alps. Mem. Ist. Geol. Mineral. Univ. Padova 30, $1-28$.

Wetzel, R. 1972: Zur Petrographie und Mineralogie der Furggzone (Monte Rosa Decke). Schweiz. Mineral. Petrogr. Mitt. 52, 161-236.

Wieland, H. 1966: Zur Geologie und Petrographie der Valle Isorno (Novara, Italia). Schweiz. Mineral. Petrogr. Mitt. 46, 189-303.

Manuscript received March 19, 2004

Revision accepted November 8, 2004 
